\title{
Urochloa in Tropical Agroecosystems
}

\author{
João Leonardo Corte Baptistella ${ }^{1}$, Sara Adrián López de Andrade ${ }^{2}$, José Laércio Favarin ${ }^{1}$ \\ and Paulo Mazzafera ${ }^{1 *}$
}

${ }^{1}$ Department of Crop Science, Luiz de Queiroz College of Agriculture - ESALQ/USP, Piracicaba, Brazil, ${ }^{2}$ Department of Plant Biology, Institute of Biology, University of Campinas-UNICAMP, Campinas, Brazil

Increasing biodiversity is an important issue in more secure and sustainable agriculture. Diversified systems are more resilient to climate change, environmental stresses and enhance soil health, nutrient cycling and nutrient use efficiency. In tropical agroecosystems, cover crops and intercrops are an alternative toward a more diverse and sustainable production. Urochloa spp. (syn. Brachiaria spp.) are perennial grasses, known for their high biomass production. They are commonly used as cover and companion crops in conservation agriculture in the tropics and the residues left in the field after cutting protect the soil and provide nutrient to the next crop cycle or intercropped culture. Urochloa species roots are vigorous, abundant and deep, as opposed to the more shallow and scarce roots of common crops. These traits contribute to carbon

OPEN ACCESS

Edited by:

Matteo Balderacchi, Independent Researcher, Piacenza,

Italy

Reviewed by:

Hannes Karwat,

International Maize and Wheat

Improvement Center, Mexico Roberta Boselli,

Catholic University of the Sacred

Heart, Italy

*Correspondence:

Paulo Mazzafera pmazza@unicamp.br

Specialty section:

This article was submitted to Crop Biology and Sustainability, a section of the journal

Frontiers in Sustainable Food Systems

Received: 19 March 2020

Accepted: 30 June 2020

Published: 05 August 2020

Citation:

Baptistella JLC, Andrade SAL, Favarin $J L$ and Mazzafera P (2020) Urochloa

in Tropical Agroecosystems.

Front. Sustain. Food Syst. 4:119

doi: 10.3389/fsufs.2020.00119 sequestration, soil organic matter stabilization and nutrient cycling. Urochloa roots also improve soil physical characteristics and influence soil nutrient dynamics, reducing nutrient losses and enhancing cycling, what is key to achieve greater nutrient use efficiency in agriculture. For instance, Urochloa root exudates can reduce nitrogen losses by denitrification and leaching through a process called biological nitrification inhibition; root exudates can mobilize recalcitrant phosphorus from soils and make it available for plant uptake; the deep roots of these grasses have the potential to recover nutrients that are virtually lost away from the root zone of other crops. This review compiles scientific progress regarding the introduction of Urochloa in agroecosystems, mainly on the aspects related to the contribution to more secure and sustainable agriculture.

Keywords: brachiaria, nutrient use efficiency, sustainability, crop production, nitrogen use efficiency, intercrop, no-till system, soil carbon stock

\section{INTRODUCTION}

It is well-known that in natural systems where there is greater diversity in plant species there is also a tendency for an increase in the natural fertility of the soil (Dybzinski et al., 2008). Several factors may be involved in this process, from the incorporation of organic matter of different plant sources to the diversity of root structures. This contributes not only to explore a greater volume of soil, and to the formation of new pores in the soil, but also to diversifying the composition of root exudates and mucilage, which results in the recruitment of specific rhizosphere microbiota for each species, promoting the interaction of plants with microorganisms and with soil nutrients (Andreote and Pereira e Silva, 2017). Therefore, it is possible to extend this information to agroecosystems, where it becomes evident that the greater diversity of species results in benefits ranging from increased productivity, greater resilience, enhanced nutrient cycling and an altogether safer and more sustainable food production (Altieri, 1999; Frison et al., 2011). 
There is a wide variety of conservation agriculture (CA) practices that are used in the tropics and subtropics. CA relies on conservation premises, such as minimum tillage, crop rotation/intercrop and permanent soil cover with crop or cover crop derived residues (Hobbs et al., 2008). CA can be applied to annual and/or perennial crop systems and their adoption depends on climate regional differences, crop management, cash crop and spatial/temporal disposition of plant species in the cultivated areas (Gil et al., 2015; Bieluczyk et al., 2020). Because CA practices have similarities to other conventional systems, the transition from conventional agriculture systems is relatively simple and it can be applied and/or adapted to large areas (Gil et al., 2015).

Most studied and common CA systems adopted in the tropics include no-tillage (NT), with grain production, cover crops and crop rotation; integrated crop-forestry system (ICFS), with simultaneous production of grains and trees; integrated croplivestock system (ICLS), with the production of grains, forage and animals; integrated livestock-forestry system (ILFS), with the production of forage, animals and trees; and integrated croplivestock-forestry system (ICLFS), with the production of grains, forage, animals, and trees (Carvalho et al., 2014; Gil et al., 2015; Bieluczyk et al., 2020). These systems can be seen as levels of complexity and intensification, NT being the less intensified, ICLFS the most and ICFS/ICLS/IFLS intermediates, which means that the more species (plant and/or animal) are introduced, the more the agroecosystem resembles a natural ecosystem, and interactions among species become more complex and more total biomass is produced (Bieluczyk et al., 2020).

In all CA systems described above, there is the opportunity to include forages to serve either as cover crops or pasture to animals. Introduction of forage species is justified when it provides services to the agroecosystem (Foley et al., 2005; Cherr et al., 2006). These services may be related to nutrient supply, increased nutrient use efficiency (NUE), soil protection and health, weed suppression and/or to the enhancement of crop or companion crop production and yields; also, they should be suited to local socioeconomic context (Cherr et al., 2006; Horrocks et al., 2019; Paul et al., 2020). Some plant traits are linked to the provision of these services, such as adaptation to tropical environmental conditions, low soil fertility requirements, high biomass production capacity, biomass recalcitrance, efficient root morphology and exudation activity, to name a few (Cherr et al., 2006; Horrocks et al., 2019).

Urochloa is a genus of perennial C4 grasses used as cover crops and as pastures. In Brazil and other South American countries, Urochloa species represent the forage with the largest pasture area (Rao et al., 1995; Dias-Filho, 2016) and their use in intercropping systems with annual and/or perennial cash crops has grown substantially in recent years, thanks to the adoption of CA practices in the tropics (Ragassi et al., 2013; Almeida et al., 2017a). There is evident scientific interest in the agronomic characteristics of Urochloa species. The International Center for Tropical Agriculture (CIAT) maintains a germplasm bank of more than 600 accessions of Urochloa spp., which can be used in breeding programs (Keller-Grein et al., 1996) or investigated for desirable traits for soil health improvement
(Horrocks et al., 2019). The interest on this genus is justified for the genetic variability found for tolerance to drought, flooding, nutritional limitation, soil acidity, and against several diseases. The cultivation of Urochloa reveals positive characteristics related to soil quality and health in agroecosystems, such as greater NUE, less risk of erosion, better soil structure, higher levels of organic matter and biological activity (Boddey et al., 1996).

Because Urochloa species produce large amounts of biomass and have a vigorous, abundant and deep root system, these plants can explore a large volume of soil and absorb substantial amounts of nutrients available in soil regions that are away from the roots of the companion crop, which are generally more superficial and scarce (Rosolem et al., 2017). Additionally, by adding and stabilizing soil organic matter, studies have shown that Urochloa roots influence the mobility and availability of some nutrients in the soil, reducing losses and benefiting the cycling process (Almeida and Rosolem, 2016; Nuñez et al., 2018). For example, certain Urochloa radicular exudates can reduce nitrogen $(\mathrm{N})$ losses, through leaching and denitrification, by preventing the nitrification process from occurring through biological nitrification inhibition (BNI) (Ishikawa et al., 2003; Subbarao et al., 2009; Byrnes et al., 2017; Nuñez et al., 2018) and in the case of phosphorus (P), exudates can mobilize recalcitrant forms of soil $\mathrm{P}$, making it available for plant absorption (Janegitz et al., 2013; Almeida and Rosolem, 2016). Urochloa can also affect directly the NUE of agroecosystems, a key aspect for food production sustainability (Hobbs et al., 2008).

The aim of this review is to gather the current state of knowledge on Urochloa grasses use in agroecosystems, with main focus as intercrop in tropical regions. For a comprehensive review we searched the databases Web of Science, Scopus, Scielo, and Google Scholar, with special attention to the most recent articles. We also included references of our own reference libraries, which are not available in these databases. "Brachiaria," "Urochloa," "intercropping," and "agroecosystems" were among the key terms used in this search, resulting in 182 references.

\section{UROCHLOA IN TROPICAL AND SUBTROPICAL CONSERVATION AGRICULTURE}

Although Urochloa is increasingly being adopted as cover and companion crop in agricultural systems through the tropics, other grasses and leguminous have also been used as rotation or cover crops in CA, such as Megathyrsus maximus [syn Panicum spp.], Stylosanthes spp., and Desmodium spp., amongst other less explored species (Jank et al., 2017). This variety of species gives complexity to the matter and simplified approaches regarding forage species choice might not be adequate as it has to provide multiple benefits to the system (Cherr et al., 2006; Paul et al., 2020). Few studies are comparing Urochloa and other species.

M. maximus is the second largest utilized grass species in the tropics (Dias-Filho, 2016). It is the most productive tropical forage multiplicated by seed (Jank et al., 2011) and it has been used successfully in intercropping systems with corn (Almeida et al., 2017b). There are several commercial cultivars of $M$. 
maximus, almost all with tufted growth habit (Jank et al., 2011). They need frequent management interventions (Jank et al., 2011; Santos et al., 2012) and demand high fertility environments, without $\mathrm{N}$ limitations, what may result in low BNI capacity (Subbarao et al., 2007, 2009; Simon et al., 2020) and subsequent higher $\mathrm{N}_{2} \mathrm{O}$ emissions than Urochloa (Subbarao et al., 2007). Simon et al. (2020) found $20 \%$ greater $\mathrm{N}_{2} \mathrm{O}$ emissions from cattle urine over M. maximus pastures, compared to that in pastures of U. humidicola.

However, M. maximus BNI capacity is still debatable. In a greenhouse experiment, Villegas et al. (2020) compared BNI capacity, $\mathrm{N}_{2} \mathrm{O}$ emission, forage productivity and quality of 119 M. maximus germplasm accessions, including four commercial cultivars (Mombaza, Sabanera, Vencedor, and Massai) and $U$. humidicola as control. The authors reported that different levels of BNI are spread through the analyzed population of $M$. maximus, but none of the 4 commercial cultivars showed high BNI capacity. Some accessions showed reduced nitrification rates, similar to $U$. humidicola, specially cultivar Tobiata, which showed the lowest values among all accessions. High BNI accessions had equal cumulative $\mathrm{N}_{2} \mathrm{O}$ emissions to U. humidicola, but low BNI accessions emitted twice as much $\mathrm{N}_{2} \mathrm{O}$. This is the first study showing high BNI capacity in M. maximus.

Horrocks et al. (2019) compared the influence of two genotypes of $U$. humidicola, two of M. maximus and $U$. hybrid $\mathrm{cv}$. Mulato I on soil health. The soil organic carbon, aggregate stability and friability were highest with the $U$. humidicola genotypes. Less soil loss was also observed in the plots with these materials. $U$. hybrid $\mathrm{cv}$. Mulato I had an intermediate effect but tended to be more alike M. maximus. The authors highlighted that these differences are related to one important, but less considered aspect, the forage growth habit. As $U$. hybrid cv. Mulato I and M. maximus grow in clumps, the benefits they add to soil are restricted to areas near the plant tussock as they leave more soil areas uncovered. As U. humidicola and other Urochloa species cover all soil, their benefits on soil traits reach the whole area. Forage growth habits and their relationship to the benefits they add to the system it is not well-understood and should be investigated further by research.

Relatively to grasses, forage legumes are less utilized in the tropics (Karia et al., 2011). But, their ability to biologically fix $\mathrm{N}$ is of particular interest, although they usually produce less biomass (Paul et al., 2020) and have lower NUE than grasses (Rao, 2001). Additionally, because they have low C:N ratio, the intense soil microbial activity in the tropics accelerates residue decomposition, as opposed to the more recalcitrant residues of grasses, which provides longer periods of soil cover (Gerlach et al., 2019; Soratto et al., 2019). However, it should be noted that intercropping legume with Urochloa species may increase its benefits to the system (Fisher et al., 1994; Costa et al., 2012).

Stylosanthes spp. are native of tropical Americas and used in Africa and Australia, being adapted to low rainfall and low soil fertility (Karia et al., 2011; Philp et al., 2019). The main uses of Stylosanthes are as green manure and in intercrops with perennial crops or grasses in pastures (Karia et al., 2011). Depending on the cultivar, Stylosanthes spp. can fix up to $200 \mathrm{~kg} \mathrm{~N} \mathrm{ha}^{-1}$, but is less productive and tolerant to grazing than Urochloa or $M$. maximus (Karia et al., 2011; Philp et al., 2019). Gerlach et al. (2019) studied the intercropping of the legumes Sylosanthes capitate, Cajanus cajan, and Crotalaria spectabilis with corn for three consecutive years in the Brazilian savanna (Cerrado). All species were monocropped or intercropped between the rows of corn either on the day of corn planting or after the corn had 4-5 fully expanded leaves. All corn-legume intercropping treatments produced more total biomass compared to corn monoculture, however, no increase on corn yield was obtained and S. capitata hardly passed $130 \mathrm{~kg}$ dry mass $\mathrm{ha}^{-1}$ when intercropped, what was low compared with the other species.

The genus Desmodium spp. comprises leguminous forages species that are native from tropical and subtropical regions and are suitable to be used in intercrops, as cover and forage crop (Paul et al., 2020). In low input agroecosystems Desmodium spp. have demonstrated great potential in improving corn yield and soil C stock (Chidowe et al., 2019), as well as suppressing aggressive weeds, like Striga hermonthica, when intercropped or in rotation with corn (Khan et al., 2006; Midega et al., 2013). Like many other leguminous in the tropics, Desmodium spp. residue showed low recalcitrance and half-life of residues covering the soil was only 29 days (Dubeux et al., 2007).

As the available literature is concerned, Urochloa can provide more services to tropical agroecosystems. In CA, Urochloa can be introduced as a sole crop, for covering the soil or combined with annual or perennial crops in intercrop systems in a variety of ways. But how should Urochloa be combined with crops or introduced in the system? To answer that, we took Brazil as an example of CA evolution and research.

Facing pasture and land degradation back in the 80 s, Brazilian agriculture and livestock production had to evolve. First, empirically by farmers, and then supported by research institutions, the use of Urochloa in intercrop systems made the restoration of agricultural and pasture productivity feasible, leading to the creation of two successful systems: "Sistema Barreirão" in 1991 (Oliveira et al., 1996) and "Sistema Santa Fé," 10 years later (Kluthcouski et al., 2000) by EMBRAPA (Empresa Brasileira de Pesquisa Agropecuária). Both systems rely on diluting costs of forage implantation/restoration by intercropping Urochloa with grain crops, where the development of the forage is improved by residual fertilizers from the cash crop after its harvest (Ceccon, 2013).

In the "Sistema Barreirão," annual crops like corn, sorghum (Sorghum bicolor), pearl millet (Pennisetum glaucum) and particularly upland rice (Oryza sativa), were intercropped with forages, such as Urochloa and Andropogon spp. to establish new pasture for cattle; on the other hand, in "Sistema Santa Fé" the intercrop is established every year and aims at producing forage for the off-season and residues in quantity and quality to cover the soil under CA (Torres et al., 2018). The research and promotion of these intercrop systems made possible the adoption and development of more integrative CA systems (ICLS, ICF, ILF, and ICLF) and Brazilian agriculture became more integrative and sustainable along the process. These two basic systems can be used as guidance to introduce Urochloa in tropical agroecosystems and be adapted to the local context. 
With annual crops, most commonly corn, Urochloa can be sowed before, during or after corn sowing; mixed to corn fertilizers, in special seed boxes between the corn ones or broadcasted before or after corn emergence (Ceccon et al., 2013). Either way, both species will coexist through the corn cycle. To guarantee no corn yield loss, forage growth must be partially suppressed to reduce competition for water, light, nutrients and space with corn; consequently, corn gains a competitive advantage over the forage, which can lead to normal growth, development and production during the intercrop without compromising forage production afterwards (Ceccon et al., 2013; de Oliveira et al., 2019). Broadcasting Urochloa before/after corn can be a way to reduce its growth (Ceccon et al., 2013) and the use of lower herbicide rates is also recommended for this aim (Almeida et al., 2018d; de Oliveira et al., 2019). In this case, nicosulfuron (2-[[[[(4, 6-dimethoxy-2pyrimidinyl) amino] carbonyl] amino] sulfonyl]-N, N-dimethyl3-pyridinecarboxamide) is the most used herbicide to suppress Urochloa growth in intercropping systems (Almeida et al., 2018d; de Oliveira et al., 2019). According to Anésio et al. (2017), applying nicosulfuron to Urochloa at a lower rate affords the suppression needed, without killing it. After corn harvest, the forage can be used as a cover crop or for grazing. This process can be repeated every year in NT, to generate residues for the next crop; or when the pasture needs to be renewed in systems that include the animal component.

More recently, Urochloa has been intercropped with perennial crops, such as coffee (Franco Junior et al., 2019; Silva et al., 2019) and citrus (Auler et al., 2008; Martinelli et al., 2017). Cultivated as stripes between rows, Urochloa protects the soil, reduces erosion, increases infiltration, suppresses weeds and cycles nutrients (Auler et al., 2008; Ragassi et al., 2013; Favarin et al., 2018). The forage can be either sowed between the rows of producing crops or sowed in the total area before the perennial crop establishment. As an aggressive forage species, Urochloa must be controlled to maintain at least $0.5 \mathrm{~m}$ distance from the plants to avoid competition for resources and mainly to facilitate crop management. This is usually done by applying herbicides periodically and by ecological mowing of Urochloa shoot when flowering, directing its residues toward the crop row (Martinelli et al., 2017; Favarin et al., 2018). As Urochloa growth is reduced dramatically under low light availability, the establishment of the intercropped system must take in consideration the sun path, the row spacing and the height of the perennial crop. In drastic situations, pruning of the crop may be necessary to avoid forage re-sowing.

In intercrops, a larger volume of soil is explored, both between the rows and at depth, depending on the agronomic characteristics of the crops chosen for cultivation. In NT systems, Urochloa produces large amounts of residues, which contribute to the increase of the SOM and to reduce soil erosion, water and nutrients runoff and water evaporation (Tully and Ryals, 2017; Tanaka et al., 2019). Both crop rotation and intercrop favor the cycling of nutrients, as they increase the efficiency in the use of fertilizers and nutrients (Pedrosa, 2013), in addition to recovering elements virtually lost beyond the reach of the root system of the main crop (Maciel de Oliveira et al., 2020).

\section{Urochloa As an Invasive Species}

Every exotic introduced species may be a potential threat to ecosystem native biodiversity, especially if the species has aggressive growth and is adapted to local edaphoclimatic conditions (Pivello et al., 1999a,b; Foxcroft et al., 2010). This is the case of most of the native African grasses introduced in the American neotropical savannas and Australia, for example (Foxcroft et al., 2010).

Urochloa species can outcompete native forage species in savannas grasslands because they have efficient photosynthetic rates, high water and nutrient use efficiency, are relatively tolerant to abiotic stresses and produce significant amounts of above and belowground biomass (Pivello et al., 1999a,b; Foxcroft et al., 2010). But its invasive character is particularly linked to prior ecosystem disturbance, i.e., usually, Urochloa is not the agent of disturbance, but a consequence of it (Vitousek et al., 1996; Zenni and Ziller, 2011). Alien grasses, such as Urochloa that are nearby an area that has been cleared or set on fire, can invade the area after the disturbance and dominate. Once established, it changes the microclimate, the quantity and quality of residues and the propensity to new fires, creating new fire regimes (GorgoneBarbosa et al., 2016). Additionally, Urochloa is well-adapted to fire in its original habitat meaning that it remains in the area even after new fire events, thus in a long term suppressing native species regeneration (Vitousek et al., 1996).

Nonetheless, because $U$. decumbens is highly colonized by AM, it has been used in initial stages of land restoration programs in disturbed areas, where other species do not grow well under harsh soil conditions (Leite et al., 2019). Also, Urochloa is highly responsive to the increased availability of nutrients after fires (Pereira-Silva et al., 2019).

Most of the risk posed by Urochloa species introduction into savanna biome is related to lack of good management practices. Thus, it is necessary to define practices to avoid dispersal and further negative effects on the native ecosystems in which the agroecosystems may be inserted. Also, pasture/cover crops should be managed and suppressed when needed, to avoid disturbances to nearby native grasslands. This may be done regularly when Urochloa is used as intercrop or as a cover crop by adopting desiccating management or mowing; when used in pastures, the grazing regime can prevent over-accumulation of residues, that are flammable, avoiding disturbances occurrence and the spread of fire and seeds to new native grassland areas (Sühs et al., 2020).

\section{NUTRIENT CYCLING BY UROCHLOA IN CONSERVATION AGRICULTURE}

Nutrient cycling comprises the many transformations nutrients undergo in the soil-plant-atmosphere system. In agroecosystems, nutrient cycling is influenced by soil and climate conditions, landscape disposition and agricultural management practices (Tully and Ryals, 2017). Thus, factors intrinsically related to the soil and landscape, such as mineralogy, texture, groundwater depth, and topography; together with climatic factors, such as 
rainfall and temperature; and plant diversity, govern nutrient flows in agroecosystems (Tully and Ryals, 2017).

The efficient use of nutrients in agriculture is vital for system sustainability and it is intimately linked to nutrient cycling, that can be optimized through the adoption of management practices to maintain soil fertility and biodiversity, increase soil $\mathrm{C}$ sequestration and minimize negative climatic effects (Power, 2010). In this context, nutrient cycling can be considered a process favored by CA systems.

Mainly because of its rapid growth and large amounts of biomass/residues produced in tropical conditions, Urochloa stand out among cover and intercrop species, such as crotalarias (Crotalaria spp.) and millet (Pennisetum spp.) (Wutke et al., 2014). Besides, Urochloa are low soil fertility demanding species (Rao et al., 1996; Miles et al., 2004). Even influenced by seasonal variations, perennial grasses, such as Urochloa, have a wider opportunity to grow and absorb nutrients throughout the year than annual crops. Therefore, they have a great influence on how and when released nutrients are available (Tully and Ryals, 2017). Senescence and pruning/cutting management or desiccation of aboveground parts of cover crops constitute the main route in which nutrients return to the soil after decomposition/mineralization of the residues, closing the cycle. Besides, perennial grasses can build up dense root systems over time, and also affect the dynamic of nutrient cycling in the soil and consequently soil fertility profile (Yé et al., 2017).

\section{Shoot Biomass and Nutrient Accumulation in Urochloa}

The cycling potential of any plant species depends on nutrient accumulation and its rate of residue decomposition. The plant cycle, that is, the time that it remains in the field, also influences this potential, as it can enable a greater accumulation of nutrients. The accumulation of nutrients is defined by the productivity of dry mass ( $\mathrm{kg}$ of dry matter ha ${ }^{-1}$ ) and the concentration of nutrients in the plant tissues $\left(\mathrm{g} \mathrm{kg}^{-1}\right)$. The higher these two factors, the higher the accumulation of nutrients will be.

Urochloa can accumulate between 2 and $16 \mathrm{Mg}$ of dry matter ha $\mathrm{h}^{-1}$ in their aerial parts, per year, in crop rotation or intercropping (Macedo, 2009; Bernardes et al., 2010; Costa et al., 2016; São Miguel et al., 2018), with the amount varying according to the species and the system management practices adopted, such as fertilization and cutting timing/frequency.

The large production of biomass combined with the relatively high concentrations of nutrients in the tissues (Table 1) results in a significative accumulation of nutrients in the Urochloa shoot (Table 2). According to the species and system management, nutrient accumulation will differ. In general, Urochloa species accumulate about $100 \mathrm{~kg} \mathrm{ha}^{-1}$ of $\mathrm{N}$ and $130 \mathrm{~kg} \mathrm{ha}^{-1}$ of potassium (K), in addition to more than $15 \mathrm{~kg} \mathrm{ha}^{-1}$ of $\mathrm{P}, 40 \mathrm{~kg} \mathrm{ha}^{-1}$ of calcium (Ca) and about $25 \mathrm{~kg} \mathrm{ha}^{-1}$ of magnesium (Mg).

It is of special relevance to know what part of the soil profile the accumulated nutrients originate from, that is, from what position in the soil they were absorbed (surface, subsurface, between cropping rows) by the roots. This information is not yet available and to obtain it, it is imperative to deepen our
TABLE 1 | Concentration of nutrients in the shoot of Urochloa.

\begin{tabular}{llllll}
\hline $\mathbf{N}$ & $\mathbf{P}$ & $\mathbf{K}$ & $\mathbf{C a}$ & $\mathbf{M g}$ & References \\
\hline $\mathbf{g ~ k \mathbf { ~ g } ^ { - \mathbf { 1 } }}$ & & & & & \\
11.7 & 2.2 & 24.8 & 2.2 & 2.4 & de Magalhães et al., 2002 \\
12.2 & 1.7 & 21.9 & 2.8 & 3.7 & Cruz et al., 2008 \\
24.3 & 1.8 & 18.0 & 3.9 & 2.9 & Costa et al., 2017 \\
\hline $\mathbf{1 6 . 1}$ & $\mathbf{1 . 9}$ & $\mathbf{2 1 . 6}$ & $\mathbf{3 . 0}$ & $\mathbf{3 . 0}$ & Mean values \\
\hline
\end{tabular}

N, nitrogen; P, phosphorus; K, potassium; Ca, calcium; and Mg, magnesium.

TABLE 2 | Nutrient accumulation in the shoot of Urochloa species.

\begin{tabular}{|c|c|c|c|c|c|c|}
\hline \multirow[t]{2}{*}{ Urochloa } & $\mathbf{N}$ & $\mathbf{P}$ & $\mathbf{K}$ & $\mathrm{Ca}$ & Mg & \multirow[t]{2}{*}{ References } \\
\hline & \multicolumn{5}{|c|}{$\mathbf{k g ~ h a}^{-1}$} & \\
\hline \multirow{11}{*}{$\begin{array}{l}\text { Urochloa } \\
\text { brizantha }\end{array}$} & 60 & 12 & 130 & 12 & 13 & de Magalhães et al., 2002 \\
\hline & 86 & 8 & ni & 14 & 14 & Torres et al., 2008 \\
\hline & 48 & 11 & 165 & 23 & 17 & $\begin{array}{l}\text { de Barcellos Ferreira et al., } \\
2010\end{array}$ \\
\hline & 135 & 13 & 118 & 87 & 45 & Pacheco et al., 2013a \\
\hline & 165 & 45 & 246 & 77 & 31 & \\
\hline & 106 & 21 & 154 & ni & ni & Costa et al., 2014a \\
\hline & 87 & 24 & 101 & 15 & 13 & Costa et al., 2014b \\
\hline & 57 & 11 & 103 & 13 & 11 & \\
\hline & 120 & 12 & 164 & 12 & 18 & Costa et al., 2015 \\
\hline & 143 & 14 & 127 & 91 & 59 & \\
\hline & 103 & 13 & 117 & 35 & 23 & Costa et al., 2016 \\
\hline Mean values & 101 & 17 & 142 & 38 & 24 & \\
\hline \multirow{9}{*}{$\begin{array}{l}\text { Urochloa } \\
\text { ruziziensis }\end{array}$} & 156 & 12 & 119 & 63 & 35 & Pacheco et al., 2011 \\
\hline & 144 & 12 & 119 & 63 & 37 & Pacheco et al., 2013a \\
\hline & 162 & 44 & 211 & 111 & 28 & \\
\hline & 121 & 35 & 79 & 24 & 22 & Pacheco et al., 2013b \\
\hline & 138 & 20 & 203 & ni & ni & Costa et al., 2014a \\
\hline & 74 & 19 & 83 & 15 & 12 & \\
\hline & 57 & 11 & 101 & 16 & 11 & Costa et al., 2014b \\
\hline & 44 & 16 & 104 & 32 & 23 & São Miguel et al., 2018 \\
\hline & 94 & 18 & 46 & 46 & 35 & \\
\hline Mean values & 110 & 21 & 118 & 46 & 25 & \\
\hline \multirow{2}{*}{$\begin{array}{l}\text { Urochloa } \\
\text { decumbens }\end{array}$} & 31 & 4 & 12 & 16 & 8 & Alcântara et al., 2000 \\
\hline & 142 & 20 & 254 & 33 & 43 & Cruz et al., 2008 \\
\hline Mean values & 87 & 12 & 133 & 24 & 26 & \\
\hline
\end{tabular}

ni, values not informed in the report. $N$, nitrogen; $P$, phosphorus; $K$, potassium; Ca, calcium; and Mg, magnesium.

understanding of the growth dynamics of the Urochloa root system in different soils and through the profile.

\section{Urochloa Root System and Soil C Stock}

Although most studies focus on shoot biomass production, the great potential of Urochloa as a cover or intercropping culture resides in the roots. Like other tropical grasses, Urochloa 
produces more root mass compared to herbaceous legumes (Rao et al., 1996). Some reports show that the accumulation of root dry mass of Urochloa can range from 5.3 to $38 \mathrm{Mg}$ $\mathrm{ha}^{-1}$ (Razuk, 2002; Volpe et al., 2006; Apolinário et al., 2013; Saraiva et al., 2014). Considering these values and the estimated root turnover for tropical grasslands of 0.85 year $^{-1}$ (Gill and Jackson, 2000), the results indicate that up to $32 \mathrm{Mg}$ root dry mass $\mathrm{ha}^{-1}$ year ${ }^{-1}$ might be produced, thus causing great impact on soil C stocks. Furthermore, the architecture, morphology, physiology and interaction of the roots with soil microbiota help the formation and stabilization of soil aggregates, increase soil porosity, $\mathrm{C}$ sequestration and can increase the availability of nutrients and reduce its losses, influencing the cycling of these elements (Bardgett et al., 2014).

The root system of some Urochloa species can easily reach three meters in depth (Rodrigues et al., 2011). However, root biomass tends to decrease significantly with depth (Guenni et al., 2004). Deep roots of several plants have functional specialization (da Silva et al., 2011; Wang et al., 2015). These roots are thinner and have a larger diameter of conductive vessels compared to superficial roots, in addition to the greater number of vessel elements and tracheids. These attributes increase hydraulic conductivity and water uptake efficiency (Wang et al., 2015). Thus, these roots can contribute to the maintenance of plant growth and nutrition, especially when the soil superficial layers are under water deficit (Bleby et al., 2010; da Silva et al., 2011). Additionally, the formation of aerenchyma as a "constitutive" characteristic of some species' roots, such as U. humidicola, gives this species high adaptability in situations of flooding and nutritional deficiencies, without impairing nutrient uptake and plant growth (de la Jiménez et al., 2019). It is known that under nutritional limitation, ethylene accumulates in the roots and induces the formation of aerenchyma and the development of new lateral roots, characteristics that are related to lower metabolic cost of the roots and lower cost of soil exploration (Postma and Lynch, 2011; de la Jiménez et al., 2019). A detailed study of Urochloa root systems could clarify whether this functional variation exists and what is the contribution to plant survival in times of drought and nutrient and water absorption at greater depths.

Generally, the amount of nutrients in the subsoil is lower than in the topsoil (Brady and Weil, 2013) but this varies with soil texture, rainfall distribution, management and especially according to the chemical transformations and interaction of each nutrient in the soil particles. However, this may not be the rule depending on the nutrient. For example, Mekonnen et al. (1997) quantified the $\mathrm{NO}_{3}^{-}$in tropical soil and found between 40 and $199 \mathrm{~kg} \mathrm{ha}^{-1}$ from the topsoil to the subsoil at $4 \mathrm{~m}$. Therefore, the absorption of nutrients from deep layers would allow these nutrients to be used for plant growth and development. Thus, it is reasonable to admit that because the large and deep root system Urochloa can reduce the loss of nutrients by absorbing them from superficial and deep soil layers.

Urochloa root system growth is not strongly limited in compacted soils (Silva et al., 1992; Barreto et al., 2006; Stumpf et al., 2016). Stumpf et al. (2016) reported that among several perennial grasses growing in a constructed mine-soil recovery,
U. brizantha roots had the highest potential to penetrate the compacted zone under the first $0.1 \mathrm{~m}$, reconstituting aggregates and thus recovering soil physical properties. According to these authors, the high density, volume and length of $U$. brizantha roots make this species a good candidate for soil decompression. The formation of aggregates of larger diameters in soil cultivated with forage grass species, including Urochloa, is related to its abundant root systems and the constant renewal and decomposition of root biomass (root turnover) (Six et al., 2004). In Kenya, the cultivation of Urochloa species was compared to other local grass species (Chloris gayana and Pennisetum purpureum) in their capability to change the size and distribution of soil aggregates (Gichangi et al., 2017). Urochloa species significantly improved soil aggregation and enhanced soil microbial biomass carbon.

The Urochloa root system can substantially increase C storage in the soil by producing massive root biomass in comparison to other species (Gichangi et al., 2017). However, this depends on how Urochloa is managed (Carvalho et al., 2010). Agronomically well-managed Urochloa pastures in the Brazilian Amazonia, with adequate liming, fertilization and cutting/grazing regimes, had great potential to increase soil $\mathrm{C}$ stocks and reduce $\mathrm{CO}_{2}$ emissions (Eri et al., 2020), because of greater biomass production and greater cattle yields per unit area (de Figueiredo et al., 2017). According to Carvalho et al. (2014), CA systems are a good way to mitigate greenhouse gas emissions on Brazilian Cerrado. On the other hand, degraded pastures are prone to $\mathrm{C}$ losses and higher $\mathrm{CO}_{2}$ emissions (Carvalho et al., 2010).

A classic study on the impact of deep-rooted grasses on soil C stocks in American neotropical savannas was done by Fisher et al. (1994). The authors reported that under agronomically wellmanaged grass-based pastures (U. humidicola and Andropogon gayanus) soil stored significant amounts of C (4.3 Mg C year $\left.{ }^{-1}\right)$ in deeper layers, which reached $1.0 \mathrm{~m}$ depth; significantly higher if compared to native savanna grasses. In the same study, $U$. humidicola/Arachis pintoi intercrop showed a greater increase, $11.7 \mathrm{Mg} \mathrm{ha}^{-1}$ year ${ }^{-1}$, suggesting that the legume's ability to fix $\mathrm{N}$ improved C sequestration in the system.

Multivariate geostatistics were used by Tavanti et al. (2020) to estimate $\mathrm{CO}_{2}$ emissions from soil under degraded pastures areas in Central Brazil, and it was verified that sorghum intercropped with $U$. brizantha promoted organic carbon storage in the mineral fraction of the soil, which consequently reduced soil $\mathrm{CO}_{2}$ emissions. The proposed pasture management with intercropped systems deserves further studies in the actual climate change scenario considering other management practices as liming and fertilizers application or grazing intensities (Tavanti et al., 2020).

Nonetheless, some recent studies show less optimistic C storage capacities in Urochloa-based pastures. For example, in agronomically well-managed Urochloa pastures, C storage was around $0.44 \mathrm{Mg} \mathrm{C} \mathrm{ha}{ }^{-1}$ year ${ }^{-1}$ (Carvalho et al., 2010), which can go up to $3.0 \mathrm{Mg} \mathrm{ha}^{-1}$ year ${ }^{-1}$ (Bustamante et al., 2006); in the ICLS, carbon storage by pastures grasses vary from 1.0 to $2.5 \mathrm{Mg} \mathrm{ha}^{-1}$ year ${ }^{-1}$, depending on the prevalent edaphoclimatic conditions and management practices (Carvalho et al., 2010). The inclusion of U. ruziziensis to a soybean-corncotton ICLS promoted soil C sequestration and the system 
became a significant $\mathrm{C}$ sink, with rates reaching $0.36 \mathrm{Mg} \mathrm{C} \mathrm{ha}^{-1}$ year $^{-1}$ (Carvalho et al., 2014). Intensifying system productivity through ICLS showed to be the best alternative in increasing soil C storage in a six-year evaluation experiment (Bieluczyk et al., 2020), accumulating $0.28 \mathrm{Mg}$ carbon $\mathrm{ha}^{-1}$ year ${ }^{-1}$. These authors observed that corn- $U$. brizantha cv. Piatã intercrop promoted the increase of SOM, whereas further introduction of Eucalyptus urograndis stands in the system, thus becoming an ICLFS system, reduced soil C and $\mathrm{N}$ contents, as shade limited crop and pasture growth. On the other hand, Rice et al. (2020) verified that the inclusion of Eucalyptus spp. to an Urochloa pasture added more $\mathrm{C}$ below $0.6 \mathrm{~m}$ depth, while $U$. brizantha increased $\mathrm{C}$ in the first $0.2 \mathrm{~m}$, showing complementarity between the two species, although forage shoot and root production was impaired compared to control. dos Santos et al. (2019) evaluated soil C stocks 16 years after the conversion of native vegetation to $U$. brizantha pastures (cv. Arapoti and cv. Xaraés) in Brazil and found $43.2 \mathrm{MgC} \mathrm{ha}^{-1}$ in soil derived from the pastures, an accumulation rate of $2.7 \mathrm{Mg} \mathrm{C} \mathrm{ha}^{-1}$ year ${ }^{-1}$. Soil C storage did not differ among Urochloa cultivars, but it was higher than native vegetation, especially in the first $0.3 \mathrm{~m}$ of depth, due to higher root biomass; additionally, an increase in soil C storage at $1 \mathrm{~m}$ depth was also observed. ICLS that relied on intercrops to establish Urochloa pastures increased soil C stocks (Soares et al., 2020).

Root recalcitrance and decomposition, distribution in the soil profile, rhizodeposition, and the establishment of mycorrhizal associations are root traits that contribute to SOM stabilization (Poirier et al., 2018). Roots can also indirectly impact soil C cycling due to the influence of its activity on soil microbiota. Roots with higher levels of lignin and lower levels of $\mathrm{N}$ promote soil C sequestration, by stimulating fungi growth over bacteria, which respire more $\mathrm{C}$-based substrates per unit of $\mathrm{C}$ incorporated in biomass (de Deyn et al., 2008; Bardgett et al., 2014). Thus, the abundance, depth, composition and rhizodeposition show the high potential of Urochloa species for stabilizing SOM.

\section{Rhizodeposition}

The compounds that plant roots exude during their growthexudates, mucilage, border cells-constitute what is known as rhizodeposits, which may interact with minerals in the clay fraction of the soil as well as with microorganisms in the rhizosphere (Kuzyakov and Domanski, 2000). Root exudates greatly vary in chemical composition and function and can represent about $30-50 \%$ of all fixed $\mathrm{C}$ by pasture grasses (Kuzyakov and Domanski, 2000). These exuded compounds represent an excellent energy source for rhizosphere microorganisms, which can increase their activity and favor SOM stabilization, both in topsoil and in subsoil profile (Poirier et al., 2018). Recently, diazotrophic bacteria of the genera Azospirillum and Nitrospirillum were identified in the rhizosphere of more than 20 genotypes of Urochloa (da Silva Ribeiro et al., 2019). These endophytic bacteria can colonize root tissues and the rhizosphere promoting plant growth due to their ability to fix dinitrogen, produce auxins, and siderophores, and/or solubilize phosphorus (P) and zinc ( $\mathrm{Zn}$ ) from the soil particles (da Silva Ribeiro et al., 2019). Biological nitrogen fixation (BNF) is an important input in systems that use Urochloa and will be addressed later in the $\mathrm{N}$ cycling topic.

Rhizodeposits may also inhibit soil processes mediated by microorganisms, such as nitrification (Subbarao et al., 2007) or increase micronutrient availability and plant uptake by the release of siderophores (Dakora and Phillips, 2002), or the reduction of metal phytotoxicity, such as the case of $\mathrm{Al}$ and Mn (Wenzl et al., 2002). Therefore, compounds exuded by roots play an important role in nutrient cycling in the rhizosphere, improving NUE and reducing the effect of toxic elements, possibly contributing to better plant performance and thereby constituting a promising area of research to stimulate more sustainable agriculture.

\section{N Cycling}

Nitrogen $(\mathrm{N})$ is generally the nutrient of highest demand by plants and a highly dynamic element with one of the most complex biogeochemical cycles, due to its various chemical forms in the soil-plant-atmosphere system (Brady and Weil, 2013). For agricultural production, some of the chemical transformations of $\mathrm{N}$, such as nitrification and denitrification, may represent $\mathrm{N}$ losses from the soil system, as $\mathrm{N}$ may be lost both by nitrate $\left(\mathrm{NO}_{3}^{-}\right)$leaching in the soil profile and by forming volatile compounds, such as $\mathrm{N}$ oxide forms ( $\mathrm{NO}$ and $\mathrm{N}_{2} \mathrm{O}$ ) that are released into the atmosphere.

$\mathrm{N}$ inputs to the system derive from atmospheric deposition, fertilization and BNF processes. The amount of $\mathrm{N}$ from biological fixation associated with diazotrophic bacteria on Urochloa roots can be substantial. According to Boddey and Victoria (1986), BNF can account for 30 and $40 \%$ of $\mathrm{N}$ accumulation in $U$. decumbens and $U$. humidicola, respectively. BNF contribution on total $\mathrm{N}$ accumulation of four Urochloa species (U. brizantha, $U$. decumbens, $U$. humidicola and U. ruziziensis) can account for 3-26\%, varying seasonally and between genotypes (Reis et al., 2001). Similar results were found by Silva et al. (2010), showing that BNF contributed with $10-42 \%$ of $U$. decumbens and 10$39 \%$ of $U$. humidicola total $\mathrm{N}$, depending on season and species. For example, $U$. ruziziensis increased the population of $\mathrm{N}$-fixing microorganisms in the system compared to U. brizantha and $M$. maximus (Rocha et al., 2020b). Considering that the mean $\mathrm{N}$ accumulation among Urochloa species is about $100 \mathrm{~kg} \mathrm{~N}^{-1}$ (Table 2), up to $42 \mathrm{~kg} \mathrm{~N} \mathrm{ha}^{-1}$ could be added into the soil from BNF. Urochloa and Panicum grasses used as cover crops in rotation under $\mathrm{N}$-limited conditions help to prevent $\mathrm{N}$ leaching (Rocha et al., 2020a) and its associated BNF may substantially contributed to part of the $\mathrm{N}$-demand of the subsequent maize culture (Rocha et al., 2020a,b).

The highest $\mathrm{N}$ inputs into the soil are via fertilization and can vary depending on management practices and the purpose of Urochloa cultivation, i.e., pasture, cover crop in rotation or intercropping system. In Urochloa pastures, $\mathrm{N}$ inputs through fertilization vary according to the intensification level (Pereira et al., 2018), for instance, in high input pasture systems, fertilization can reach up to $300 \mathrm{~kg} \mathrm{~N} \mathrm{ha}^{-1}$ (Santos et al., 2010), but common fertilization recommendations are $50 \mathrm{~kg}$ $\mathrm{N} \mathrm{ha}^{-1}$ for pasture maintenance and additional $50 \mathrm{~kg} \mathrm{~N} \mathrm{ha}^{-1}$ after each grazing cycle (Werner et al., 1997). When Urochloa 
is cultivated as a cover crop, $\mathrm{N}$ fertilizers might be applied at sowing at a maximum rate of $40 \mathrm{~kg} \mathrm{~N} \mathrm{ha}^{-1}$ to guarantee the establishment of the pasture (Werner et al., 1997). When Urochloa is intercropped with corn or coffee, fertilization is commonly applied uniquely to the cash crop, and in these systems, $\mathrm{N}$ inputs follow the $\mathrm{N}$ requirements of the cash-crops. In corn, $200 \mathrm{~kg} \mathrm{~N} \mathrm{ha}^{-1}$ may be used (Cantarella, 2007); in coffee, $\mathrm{N}$ fertilization may reach up to $450 \mathrm{~kg} \mathrm{~N} \mathrm{ha}^{-1}$, at an average of $300 \mathrm{~kg} \mathrm{~N} \mathrm{ha}^{-1}$ (Quaggio et al., 2018).

The main forms of $\mathrm{N}$ losses in agricultural systems are the volatilization of ammonia $\left(\mathrm{NH}_{3}\right)$, soil erosion, nitrate leaching and runoff and denitrification (Brady and Weil, 2013). Conservation practices consistently prevent $\mathrm{N}$ losses from soil erosion and runoff when compared to conventional systems (Wutke et al., 2014). The volatilization of $\mathrm{NH}_{3}$ is a more challenging issue when $\mathrm{N}$ is supplied as urea-based fertilizers, while $\mathrm{NO}_{3}^{-}$losses, by leaching and denitrification, are prone to occur in every form of $\mathrm{N}$-fertilizer (Villalba et al., 2014). In Brazil, $\mathrm{NO}_{3}^{-}$leaching can stand for the loss of up to $87 \mathrm{~kg} \mathrm{ha}^{-1}$ of $\mathrm{N}$ under favorable conditions (Villalba et al., 2014). N loss can also occur by denitrification, which is the process in which $\mathrm{NO}_{3}^{-}$is used as the final electron acceptor in anaerobic respiration and transformed into volatile forms $\left(\mathrm{N}_{\mathrm{X}} \mathrm{O}\right)$ by some groups of soil bacteria. Although denitrification $\mathrm{N}$ losses represent only about $1 \%$ of the total $\mathrm{N}$ applied (Villalba et al., 2014), they are very harmful as $\mathrm{N}_{2} \mathrm{O}$, a powerful greenhouse gas, is potentially more harmful to the environment than $\mathrm{CO}_{2}$ (IPCC, 2019).

The high $\mathrm{N}$ use efficiency of Urochloa can contribute to the reduction of $\mathrm{N}$ losses when used in intercropped systems. In an experiment using ${ }^{15} \mathrm{~N}$-enriched fertilizer in a coffeeUrochloa intercrop system, the $\mathrm{N}$ recovery efficiency increased from 38 to $53 \%$ when the element was supplied in equal doses between Urochloa and coffee plants, compared to when supplied solely to coffee plants. This value was over $80 \%$ when it was supplied only for Urochloa (Pedrosa, 2013). In the corn-Urochloa intercrop, the recovery of $\mathrm{N}$ in fertilizer was higher than in corn monoculture (Almeida et al., 2018d) and the greater recovery in soil profiles between 0.6 and $1.0 \mathrm{~m}$ was probably related to Urochloa roots reaching deep layers, thus reducing $\mathrm{N}$-losses by leaching. Reduced leaching might as well be attributed to the BNI promoted by Urochloa root exudation (Karwat et al., 2018). Also, Galdos et al. (2020) reported that the finer roots of $U$. brizantha promoted a more complex pore system in the soil, reducing solute flow and reducing $\mathrm{N}$ leaching when compared to corn or even $U$. ruziziensis.

In this context, Urochloa roots exudates can act directly on the $\mathrm{N}$ cycle, inhibiting undesirable processes in terms of production sustainability. This can contribute to the high $\mathrm{N}$ use efficiency of these tropical grasses and the decrease of $\mathrm{N}$ losses in agroecosystems.

\section{Biological Nitrification Inhibition}

The roots of certain plant species are capable of exuding substances that inhibit and/or reduce nitrification, a process carried out by bacteria of the genera Nitrosomonas and Nitrobacter, that transform ammonium $\left(\mathrm{NH}_{4}{ }^{+}\right)$to nitrite $\left(\mathrm{NO}_{2}{ }^{-}\right)$and $\mathrm{NO}_{2}{ }^{-}$to $\mathrm{NO}_{3}{ }^{-}$, respectively. This inhibitory action on this process is called biological nitrification inhibitionBNI (Ishikawa et al., 2003; Subbarao et al., 2007, 2009) and can contribute positively to the crop's $\mathrm{N}$ use efficiency (Sun et al., 2016). Several studies show the effectiveness of some compounds exuded by roots in reducing nitrification, as well as $\mathrm{NO}_{3}{ }^{-}$leaching and $\mathrm{N}_{2} \mathrm{O}$ emissions (Subbarao et al., 2009; Byrnes et al., 2017). It is important, however, to note that the main $\mathrm{N}$ form lost in soil systems is $\mathrm{NO}_{3}{ }^{-}$, due to the various chemical transformations it can undergo. For this reason, several studies addressing nitrification inhibition have been carried out.

Commercial products that inhibit nitrification exist and are used for said purpose. The most common are those based on nitrapyrin, DMPP (3,4-dimethylpyrazole phosphate) and DCD (dicyandiamide) (Trenkel, 2010). The efficiency of these compounds is questionable, and its use has been rarely translated into gains in productivity (Rosolem et al., 2017). This low efficiency may be due to environmental factors (Villalba et al., 2014) and to the fact that these inhibitors act in only one of the stages of the nitrification process (Subbarao et al., 2009), causing the inhibitory effect to last a few weeks at most (Villalba et al., 2014). The first stage of nitrification is carried out by the enzyme ammonia monooxygenase and the second by hydroxylamine oxidoreductase (Subbarao et al., 2013).

Urochloa species are capable of exuding nitrification inhibiting substances (NIS) by their roots, although their production varies according to species, cultivar and soil pH (Subbarao et al., 2007). Among the Urochloa species, $U$. humidicola and $U$. decumbens had greater inhibitory effect on nitrification compared to other grasses, cereals and legumes (Subbarao et al., 2007). Among nitrification inhibiting substances, brachialactone is responsible for more than $60 \%$ of BNI in soils under $U$. humidicola influence (Subbarao et al., 2009), which is considered the model plant species for BNI studies.

Brachialactone is a cyclic diterpene produced in the presence of the $\mathrm{NH}_{4}^{+}$ion and ensures that most of the inorganic $\mathrm{N}$ remains in this ionic form (Subbarao et al., 2009). This compound is exuded by Urochloa roots in response to the presence of $\mathrm{NH}_{4}{ }^{+}$in the rhizosphere and affects the two stages of nitrification. Brachialactone is more effective in suppressing this process when compared to the synthetic inhibitor nitrapyrin, which acts only on the enzyme ammonia monooxygenase (Subbarao et al., 2009). Although this inhibitory effect is immediate, it takes a year of cultivation for the BNI to reach its maximum (Nuñez et al., 2018). Subbarao et al. (2009) observed that after three years of Urochloa pasture establishment, nitrification and denitrification processes were strongly suppressed in the soil. Some genotypes of $U$. humidicola possess high BNI capacity and can reduce the emission of $\mathrm{N}_{2} \mathrm{O}$ (Subbarao et al., 2009). On this regard, it has been shown that $U$. humidicola significantly reduced $\mathrm{N}_{2} \mathrm{O}$ emissions from cattle urine residues in soils (Byrnes et al., 2017; Simon et al., 2020).

Pastures of tropical grasses are commonly efficient in soil $\mathrm{N}$ use and demonstrate low losses of this element (Karwat et al., 2017), so gains of BNI promoted by Urochloa would be more evident for the next crop or in the companion crop, in the case of crop rotation and intercrops, respectively. Early stages of crop development are critical for $\mathrm{N}$ loss, as the roots are still 
underdeveloped and exploit small soil volumes. As a residual BNI effect of Urochloa can last up to 4 months after cutting or desiccation-due to the accumulation of NIS in the soil during its cultivation, or to the root biomass that remains in the field releasing these inhibitors during decomposition (Karwat et al., 2017) - these losses would be reduced, with benefits to the next sown crop (Karwat et al., 2017).

The cultivation of corn in an area previously cultivated with $U$. humidicola showed higher productivity, higher $\mathrm{N}$ absorption and use efficiency compared to corn monoculture and the use of synthetic nitrification inhibitor DCD (Karwat et al., 2017). However, NIS effect does not last for long periods in soil environment, since the result did not repeat in the second corn cultivation, indicating that the residual inhibitory effect of Urochloa had ended (Karwat et al., 2017). It is expected that in intercropping systems where Urochloa is used between the rows, the effect will be more evident because of the proximity and co-occurrence of the crops.

BNI would lead to greater NUE from the soil by Urochloa roots, allowing both $\mathrm{NO}_{3}^{-}$and $\mathrm{NH}_{4}{ }^{+}$uptake, as observed by Nakamura et al. (2005) in U. humidicola. Species, such as $U$. humidicola are naturally adapted to $\mathrm{N}$-limited environments and can absorb both $\mathrm{NH}_{4}{ }^{+}$and $\mathrm{NO}_{3}{ }^{-}$. Its performance under high levels of $\mathrm{NH}_{4}{ }^{+}$is superior to that of other Urochloa species, although the growth under $\mathrm{NO}_{3}{ }^{-}$is relatively higher (Rao et al., 1996; Rao, 2001). These differences to other Urochloa species seem to be linked to the characteristic high production of NIS of $U$. humidicola, among other factors (Rao, 2001). Therefore, it is plausible that genotypes from other Urochloa species with high BNI potential also behave similarly when subjected to high concentrations of $\mathrm{NH}_{4}{ }^{+}$. As urea is frequently the main form of $\mathrm{N}$-fertilizer used in agriculture and, that when solubilized in acidic $\mathrm{pH}$ conditions it is transformed to $\mathrm{NH}_{4}{ }^{+}$, this Urochloa response would be of interest, as it could further reduce N-losses through the absorption of $\mathrm{N}-\mathrm{NH}_{4}{ }^{+}$.

\section{P Cycling}

$\mathrm{P}$ is one of the less available plant nutrients in soils (Marschner, 2012). The concentration of $\mathrm{P}$ in the soil solution rarely exceeds $10^{-4} \mathrm{M}$ (Johnston et al., 2014), with phosphate ion $\left(\mathrm{H}_{2} \mathrm{PO}_{4}{ }^{-}\right)$ diffusion being the main mechanism for this nutrient to reach the roots. Besides, inorganic $\mathrm{P}(\mathrm{Pi})$ can be retained/fixed to soil colloids, making it unavailable to plants in the short term, even though it is mobilized at small rates over the years (Syers et al., 2008; Johnston et al., 2014). Organic P (Po) can represent between 20 and $80 \%$ of the total $\mathrm{P}$ of the soil (Neumann, 2016) and the most representative organic forms of $\mathrm{P}$ in the soil are inositol phosphates or phytates, which can also be strongly fixed to the mineral surfaces of the soil, and phosphate monoesters and diesters, such as sugar-phosphates, phospholipids and nucleic acids (DNA and RNA), which have higher mobility in soil (Gerke, 2015).

Although over $50 \%$ of the $\mathrm{P}$ fixed in the soil is represented by orthophosphate $(\mathrm{Pi}), \mathrm{Po}$ as inositol phosphate can represent up to $40 \%$ of the fixed $\mathrm{P}$ depending on the soil and the cropping system, being considered a highly recalcitrant form of P (Menezes-Blackburn et al., 2017). These fixed fractions could sustain agricultural production for hundreds of years if they were made available to plants (Menezes-Blackburn et al., 2017). The inclusion of tropical grasses, such as Urochloa, in agricultural systems can contribute to the use of these poorly available $\mathrm{P}$ fractions.

Plants have mechanisms to increase the acquisition of unavailable $\mathrm{P}$ forms in the soil, among them, the exudation of surplus protons, organic acids and enzymes by the roots (Lambers et al., 2006; Louw-Gaume et al., 2017; Wang and Lambers, 2020), the emission of root hairs in a greater number and length (Wang and Lambers, 2020), in addition to the association with arbuscular mycorrhizal fungi (AMF) (Lambers et al., 2006). Acid phosphatase enzymes released in the rhizosphere by the roots are also able to release Pi from mono and diester phosphates, making it available for plant absorption (Tian and Liao, 2015). In addition, Pi fixed on soil colloids and Po can be mobilized by the action of organic acids, such as citric, oxalic, and malic acids, among others (Lambers et al., 2015).

In response to P-limitation Urochloa increases acid phosphatase activity (Louw-Gaume et al., 2010) and exudes organic acids (Louw-Gaume et al., 2017). Even at high P availability, $U$. humidicola roots showed a large exudation of acid phosphatases to the rhizosphere (Teutscherova et al., 2019). A study on the influence of green manure species on soil $\mathrm{P}$ retention showed that soil under $U$. ruziziensis as the cover crop had the lowest $\mathrm{P}$ adsorption by the colloidal fraction amongst other leguminous covers, such as Crotalaria juncea, C. cajan, and Mucuna aterrima (Silva et al., 1997). The cultivation of these same species as cover crops also reduced the maximum $\mathrm{P}$ adsorption capacity in a Rhodic Hapludox soil, but in this soil peanut (Arachis hypogaea) and sorghum also used as cover crops were the most effective in this reduction (Janegitz et al., 2017). The lower $\mathrm{P}$ adsorption capacity of soils under Urochloa cover compared to soils under legumes-based cover has been related to the lower rate of decomposition of grasses residues relative to legumes (Silva et al., 1997; Janegitz et al., 2017).

When fertilized with $\mathrm{P}$, the increase of $U$. ruziziensis exudation was related to the reduction of soil $\mathrm{P}$ recalcitrance, an effective indication of $\mathrm{P}$ cycling and mobilization in the soil-plant system (Almeida et al., 2018a). In rotation with soybean, U. ruziziensis increased the labile and moderately labile fractions of $\mathrm{P}$, reducing the residual fraction of the nutrient in the soil (Almeida and Rosolem, 2016). However, this does not necessarily translate into higher $\mathrm{P}$ absorption or higher productivity of subsequent crops (Almeida et al., 2018b,c).

Po accumulation may occur in the soils covered with vegetation (Rodrigues et al., 2016), as a result of the decomposition of plant residues on the surface and roots belowground (Zaia et al., 2008). Po fractions may be the main source of $\mathrm{P}$ in deeper layers of the soil profile, mainly originated from dead roots decomposition or even from Po mobilized in the soil profile. Oehl et al. (2002) identified a significant increase of $\mathrm{Po}$ in subsoil layers in organic and conventional agroecosystems. This fraction may be important for plant nutrition after mobilization and Pi release, especially when the levels of $\mathrm{P}$ on the soil surface decrease. On the 
other hand, the binding of $\mathrm{Pi}$ with soil organic matter and formation of metallic phytates can occur after cultivation with Urochloa, which would potentially reduce in the short term the availability of P to plants (Almeida et al., 2018b). In contrast, the cultivation of $U$. ruziziensis as a cover crop reduced the concentration of myo-inositol and labile $\mathrm{P}$ degraded by inducing soil phytase activity (Almeida et al., 2018a), especially in those soils in which phosphate fertilizers were applied. This may be due to the direct exudation of phytases by $U$. ruziziensis roots or because its organic exudates favored the activity of microbial communities capable of degrading inositol. It should be noted that myo-inositol reduction was accompanied by an equivalent increase in decomposed fractions of inositol, which are easier to be mineralized and subsequently release $\mathrm{Pi}$ to plants.

Another plant response to P-limitation is establishing symbiotic AMF. AMF colonize roots and produce extra radicular hyphae that extend through the soil, functioning as an extension of the plant's root system, thus increasing soil volume exploitation and the acquisition of nutrients, among other nonnutritional benefits to the host (Clark and Zeto, 2000; PérezTienda et al., 2012). In return, the plant provides carbohydrates and lipids as substrates for the fungus growth. The association with AMF has a lower energy cost for the plant than root hair production (Lambers et al., 2008).

Tropical C4 grasses, such as Urochloa, are highly mycotrophic and very responsive to mycorrhizal associations (Smith and Read, 2008). It has been found that in nutrient-poor pastures, Urochloa depends more on mycorrhizal fungi than C3 plants, especially in the initial seedling stages and during regrowth after periods of drought (Hetrick et al., 1990; Veenendaal et al., 1992). The use of $U$. decumbens in pastures in the Brazilian Cerrado has revealed high colonization by AMF, at a greater degree than native plants (Leite et al., 2019), which would partially explain the capacity of this species to develop in low fertility soils.

It has been suggested that in environments with low nitrification rates, where $\mathrm{NH}_{4}^{+}$predominates, arbuscular mycorrhizae may increase the efficiency of $\mathrm{N}$ and $\mathrm{P}$ utilization (Teutscherova et al., 2019). A short-term study sheds light on the relationship between mycorrhization, $\mathrm{P}$ and $\mathrm{N}$ uptake and soil phosphatase activity after ammonium-N fertilization of Urochloa genotypes with different BNI capacities. Mycorrhizal colonization of genotypes with high BNI capacities was positively correlated with acid phosphatase activity under $\mathrm{N}$ fertilization (Teutscherova et al., 2019). In this study, $U$. humidicola genotypes confirmed their high BNI capacity and maintained higher mycorrhizal colonization than low-BNI Urochloa hybrid cv. Mulato.

In a comprehensive review of $\mathrm{P}$ absorption in intercropping systems, Xue et al. (2016) reported numerous cases of mutual benefits in the absorption of $\mathrm{P}$, whether due to greater AMF colonization, plant-microbe interactions, complementary niches or absorption facilitation via root exudates or increased microbial activity. Likewise, Urochloa has various mechanisms to increase the availability of $\mathrm{P}$ and other nutrients, and their inclusion in the productive system may provide greater absorption of these nutrients by the intercropped species.

\section{K Cycling}

A few studies were carried on $\mathrm{K}$ cycling and Urochloa in agroecosystems. According to Garcia et al. (2008), U. brizantha extracts substantial amounts of $\mathrm{K}$ from subsoil layers, increasing its availability on the surface soil. This is a piece of important information, since K leaching can represent up to $50 \%$ of the total nutrient applied as fertilizer in conventional systems (Rosolem and Steiner, 2017). Unfortunately, this study did not provide detailed information on the contribution of $\mathrm{K}$ cycling from the exploration of roots from deep soil layers.

On the other hand, using rubidium $(\mathrm{Rb})$ as a marker for $\mathrm{K}$, Maciel de Oliveira et al. (2020) compared K cycling and the vertical stratification of $\mathrm{K}$ uptake in soybean cultivation followed by ruzigrass ( $U$. ruziziensis), corn or corn-ruzigrass intercrop during 2 years. In the first year, $\mathrm{K}$ accumulation was $358 \mathrm{~kg} \mathrm{ha}^{-1}$ for ruzigrass monoculture, $56 \mathrm{~kg} \mathrm{ha}^{-1}$ for corn monoculture and $184 \mathrm{~kg} \mathrm{ha}^{-1}$ for corn-ruzigrass intercrop. In the second year, $\mathrm{K}$ accumulation was in general lower, but ruzigrass monoculture and corn-ruzigrass intercrop had higher K uptake, 209 and $157 \mathrm{~kg}$ $\mathrm{ha}^{-1}$, respectively, compared to $106 \mathrm{~kg} \mathrm{ha}^{-1}$ for corn as a sole crop. These authors also showed that soil deep layers had a higher contribution for $\mathrm{K}$ uptake by ruzigrass (monoculture and intercropped with corn) in both years, as $34 \%$ of total $\mathrm{K}$ was absorbed from $0.6 \mathrm{~m}$ depth and $40 \%$ from $0.3 \mathrm{~m}$. Topsoil accounted for only $26 \%$. These results show that ruzigrass can accumulate high quantities of $\mathrm{K}$ and that most of it may come from deep soil layer.

We do not know any similar research with other nutrients and the contribution of the deep layers is also unknown. Therefore, research on the vertical stratification of nutrients uptake by Urochloa deserves more attention.

\section{Decomposition of Urochloa Residues and Nutrient Release}

Urochloa cultivation in rotation systems or as intercrop generates considerable amounts of residues above and belowground that will be prone to decomposition and mineralization (Momesso et al., 2019; Tanaka et al., 2019). However, the total amount of the nutrients released in the soil do not become fully available for plant absorption. The composition and quantity of plant residues left by a crop, alter soil nutrient cycles in complex ways (Urquiaga et al., 1998). For instance, depending on the quality (chemical nature) of the residues and the prevalent environmental conditions, nutrients, such as $\mathrm{N}$, can be either immobilized in soil/residues or mineralized and released into the soil solution, becoming available for plant uptake (Urquiaga et al., 1998; Marchezan et al., 2020). There are also nutrient losses due to volatilization and leaching during the mineralization process, and depending on residue quality, these elements may not be fully released during the next crop cycle, although they may become available in the system in the long term.

The decomposition process can be defined as the breaking of complex organic compounds into simpler and soluble compounds (Cardoso and Andreote, 2016). Soil micro and 
macrofauna regulate the process by reducing particle size which facilitates microorganism access to further chemical transformation of the organic matter. Mineralization is the process through which simpler organic molecules are degraded and transformed into inorganic forms by microorganisms, which obtain energy and nutrients necessary for its multiplication and development. Thus, part of the nutrients is immobilized in the microbial biomass and the surplus released to the environment, making it available for plant uptake (Cardoso and Andreote, 2016).

The factors that influence the activity of soil biota govern the decomposition/mineralization processes responsible for the release of nutrients. Among those factors, temperature, $\mathrm{pH}$, water availability and the chemical composition of the residue play important roles. At this respect the $\mathrm{C}: \mathrm{N}$ ratio and the content of lignin, waxes, polyphenols and tannins are especially relevant defining SOM recalcitrance (Cardoso and Andreote, 2016). The high $\mathrm{C}: \mathrm{N}$ ratios and high lignin content of the residue contribute to the temporary immobilization of $\mathrm{N}$ in the soil (Horwath, 2017) and delay decomposition/mineralization process (Pacheco et al., 2011). Residues from Urochloa species, such as U. ruziziensis, for example, have a high C:N ratio in their biomass if compared to other Poaceae residues (Souza et al., 1999) or to legumes, which have low $\mathrm{C}: \mathrm{N}$ ratio. Although it is beneficial for soil conservation to maintain soil coverage for longer periods in a tropical environment, this practice can slow down nutrients release (São Miguel et al., 2018; Momesso et al., 2019).

Residue degradation rates are established by half-life time, that is, the number of days required for $50 \%$ of residue biomass to be completely mineralized to $\mathrm{CO}_{2}$, which varies between 70 and 120 days for Urochloa (Ceballos et al., 2018; Neves et al., 2018). As the residue is decomposed, mineral nutrients are released and made available to other organisms in the system.

According to Costa et al. (2014b), it takes 6 months for $90 \%$ of all $\mathrm{P}$ and $\mathrm{K}$ and $60 \%$ of all $\mathrm{N}$ to be released from the Urochloa residue. To release half of the $\mathrm{N}, \mathrm{P}, \mathrm{K}, \mathrm{Ca}$, and $\mathrm{Mg}$ contents of the Urochloa biomass, it takes 52, 20, 16, 61, and 47 days, respectively (Costa et al., 2016). In corn-Urochloa intercrop, up to $89 \%$ of $U$. brizantha and $U$. ruziziensis residues were already decomposed 3 months after corn harvest (Momesso et al., 2019). These relatively high decomposition rates were attributed to favorable rainfall and temperature conditions during the study, and consequently, a fast nutrient release was observed, as more than $80 \%$ of all the macronutrients contained in the residues were released.

Tanaka et al. (2019) reported that depending on the growing season, the cover crop biomass production, decomposition rates and nutrient release are affected by rainfall distribution. The homogeneous rainfall distribution was responsible for great biomass production, high decomposition rate and nutrient release after 90 days of Urochloa desiccation (Tanaka et al., 2019). After this period more than $90 \%$ of the residues were decomposed and nutrients released; on the other hand, although producing fewer residues, only $74 \%$ of it was decomposed and $30 \%$ of $\mathrm{N}$ was remaining when the condition was not favorable.

Because nutrients form an array of compounds of different complexity in the plant cells, their release rates may differ. Bernardes et al. (2010) found that nutrient release from $U$. brizantha residue was lower than $P$. maximum residue after 75 days of cutting. While the first released 38, 49, 59, 35, and 55\% of the $\mathrm{N}, \mathrm{P}, \mathrm{K}, \mathrm{Ca}$, and $\mathrm{Mg}$, the later species released $55,61,70$, 40 , and $53 \%$, respectively. This difference probably reflects the chemical nature of each plant matrix (quality).

The nutrients from residues fulfill a large amount of the nutritional requirements of the companion crop or in succession, what otherwise would be supplied by the soil or by fertilization. Data in the literature support evidence that nutrients cycled via Urochloa increases use efficiency and the sustainability of the production system. On the other hand, there may be a lack of synchrony between the release of nutrients from the residues and the stage of highest demand by the crop during succession or intercropping. Regarding Urochloa intercropped with perennial crops, such as coffee and citrus, grass cutting can be programmed to coincide with the time the crop's demand is the highest. In any case, with or without synchrony, perennial crops absorb nutrients throughout the year. For annual crops in succession/intercrop, synchronization is not possible. Thus, residues release the most nutrients after cutting/degradation at the beginning of the crop cycle, when the root system is still underdeveloped and restricted to recover all the elements released in the total area, which initially, can lead to low utilization of this nutritional source.

Moreover, while residues on soil surface may not immobilize $\mathrm{N}$, root residues can decrease $\mathrm{N}$ absorption of the next crop (Rosolem et al., 2017). Root turnover is a function of climatic conditions, root diameter and composition (Gill and Jackson, 2000) and can be slower than the shoot residues (da Silva et al., 2019). According to Urquiaga et al. (1998), more root biomass increased $\mathrm{N}$ immobilization and grasses had more nondecomposable $\mathrm{C}$ in the roots, reducing decomposition process and immobilizing N. Urochloa root biomass decay was enhanced with $\mathrm{N}$ fertilization and moderate grazing (da Silva et al., 2019), but after 512 days of incubation $30 \%$ of the root biomass was remaining. Based on this, root decomposition may be higher when Urochloa is mowed and $\mathrm{N}$ fertilization for the next crop is applied. Nevertheless, there is not enough information in the literature on root grasses decomposition and nutrient supply, indicating that further research is necessary to better understand this process and the consequences for plants nutrition.

In any case, the nutrients resulting from Urochloa residue decomposition represent a way to increase NUE in CA, which in the long run generates savings in the use of fertilizers, increases the useful life of reserves and mineral deposits used to manufacture them and enables safer and more sustainable production of food.

\section{FINAL REMARKS}

CA practices are a sustainable and secure way of producing food, providing the opportunity to introduce more species than conventional systems. Introduction of forage species can provide multiple services to agroecosystems and among these species, Urochloa stands out, as far as the literature is concerned. Introduction of this grass in CA systems can be done through intercrops and crop rotation, with both annual and perennial 
cash-crops. Urochloa accumulates large amounts of residues, which will not only protect the soil but also improve soil health and $\mathrm{C}$ storage. In addition to exploiting a large volume of soil and producing a large amount of biomass, Urochloa root system can recover elements from deep soil layers and directly influence $\mathrm{N}$ and $\mathrm{P}$ cycles, with reduced losses, greater recovery efficiency and better use of fertilizers by the plant. It is important to extend our knowledge to other nutrients as most of the available literature focus on $\mathrm{N}$ and $\mathrm{P}$.

Urochloa can accumulate $\sim 100 \mathrm{~kg} \mathrm{ha}^{-1}$ of $\mathrm{N}, 130 \mathrm{~kg} \mathrm{ha}^{-1}$ of $\mathrm{K}, 15 \mathrm{~kg} \mathrm{ha}^{-1}$ of $\mathrm{P}, 40 \mathrm{~kg} \mathrm{ha}^{-1}$ of $\mathrm{Ca}$, and $25 \mathrm{~kg} \mathrm{ha}^{-1}$ of $\mathrm{Mg}$ in its shoots. Depending on residue quality, system management and edaphoclimatic conditions, these accumulated nutrients can be made available by the decomposition/mineralization processes or immobilized in the soil. Although immobilization might not be a problem for shoot residues deposited over the soil surface, root decomposition potentially immobilizes $\mathrm{N}$ due to its higher recalcitrance and reduces the next crop or companion crop uptake. Consequently, understanding root decay dynamics and how it affects nutrient cycling is important and further research is encouraged on this issue. The amount of nutrients released by the Urochloa biomass is certainly not sufficient to supply for the total demand of the intercropped or succession crops, but it can still increase NUE in agroecosystems. This occurs especially in the case of perennial crops, since the cutting can be synchronized with the plant's stage of highest demand.

It should be restated that the benefits attributed to Urochloa introduction require proper management of this grass, i.e., Urochloa should be limed, fertilized, grazed, mowed or suppressed according to recommendation standards to provide

\section{REFERENCES}

Alcântara, F. A., de Furtini Neto, A. E., Paula, M. B., de Mesquita, H. A., and de Muniz, J. A. (2000). Adubação verde na recuperação da fertilidade de um latossolo vermelho-escuro degradado. Pesqui. Agropecu. Bras. 35, 277-288. doi: 10.1590/S0100-204X2000000200006

Almeida, D. S., Menezes-Blackburn, D., Turner, B. L., Wearing, C., Haygarth, P. M., and Rosolem, C. A. (2018a). Urochloa ruziziensis cover crop increases the cycling of soil inositol phosphates. Biol. Fertil. Soils 54, 935-947. doi: 10.1007/s00374-018-1316-3

Almeida, D. S., Penn, C. J., and Rosolem, C. A. (2018b). Assessment of phosphorus availability in soil cultivated with ruzigrass. Geoderma 312, 64-73. doi: 10.1016/j.geoderma.2017.10.003

Almeida, D. S., Rocha, K. F., de Souza, M., Delai, L. B., and Rosolem, C. A. (2018c). Soil phosphorus bioavailability and soybean grain yield impaired by Ruzigrass. Agron. J. 110, 654-663. doi: 10.2134/agronj2017.08.0451

Almeida, D. S., and Rosolem, C. A. (2016). Ruzigrass grown in rotation with soybean increases soil labile phosphorus. Agron. J. 108, 2444-2452. doi: 10.2134/agronj2015.0478

Almeida, R. E. M., de Favarin, J. L., Otto, R., Franco, H., Reis, F. B., Moreira, L. A., et al. (2018d). Nitrogen recovery efficiency for corn intercropped with palisade grass. Bragantia 77, 557-566. doi: 10.1590/1678-4499.2017242

Almeida, R. E. M., de Oliveira, S. M., Lago, B. C., Junior, C. P., Trivelin, P. C. O., and Favarin, J. L. (2017a). Palisadegrass effects on N fertilizer dynamic in intercropping systems with corn. An. Acad. Bras. Cienc. 89, 1917-1923. doi: 10.1590/0001-3765201720160811

Almeida, R. E. M., Gomes, C. M., Lago, B. C., de Oliveira, S. M., Junior, C. P., and Favarin, J. L. (2017b). Corn yield, forage production and quality affected such benefits. These good practices and native ecosystems protection ensure that the species does not invade native ecosystems, which can be a problem in neotropical savanna and Australia, concerning the reduction in native biodiversity.

For these reasons and others still not well-studied, including Urochloa in tropical agroecosystems present a feasible way to increase efficiency and making agricultural production more sustainable. We underscore the importance of future studies concerning the effects of the root system on the cycling of different nutrients and in different production systems, to enable incorporating this resource.

\section{AUTHOR CONTRIBUTIONS}

$\mathrm{JB}$ and PM designed the review and together with SA and JF wrote the manuscript. All authors contributed to the article and approved the submitted version.

\section{FUNDING}

This research was partially funded by Fundação de Amparo à Pesquisa do Estado de São Paulo (FAPESP grant 2016/25498-0).

\section{ACKNOWLEDGMENTS}

JB thanks Fundação de Amparo à Pesquisa do Estado de São Paulo (FAPESP grant 2018/02497-3) for a postgraduation fellowship and PM and JF thank Conselho Nacional de Desenvolvimento Científico e Tecnológico (CNPq) for research fellowships. by methods of intercropping corn and panicum maximum. Pesqui. Agropecu. Bras. 52, 170-176. doi: 10.1590/s0100-204x2017000300004

Altieri, M. A. (1999). The Ecological Role of Biodiversity in Agroecosystems. Amsterdam: Elsevier Science BV.

Andreote, F. D., and Pereira e Silva, M. (2017). Microbial communities associated with plants: learning from nature to apply it in agriculture. Curr. Opin. Microbiol. 37, 29-34. doi: 10.1016/j.mib.2017.03.011

Anésio, A. H. C., Santos, M. V., Silveira, R. R., Ferreira, E. A., Braz, T. G. S., Tuffi Santos, L. D., et al. (2017). Seletividade de herbicidas ao capim-braquiária e capim-ruziziensis. Planta Daninha 35, 1-12. doi: 10.1590/s0100-83582017350100062

Apolinário, V. X. O., Dubeux, J. C. B., Mello, A. C. L., Vendramini, J. M. B., Lira, M. A., Santos, M. V. F., et al. (2013). Deposition and decomposition of signal grass pasture litter under varying nitrogen fertilizer and stocking rates. Agron. J. 105, 999-1004. doi: 10.2134/agronj2012.0433

Auler, P. A. M., Fidalski, J., Pavan, M. A., and Neves, C. S. V. J. (2008). Produção de laranja "Pêra" em sistemas de preparo de solo e manejo nas entrelinhas. Rev. Bras. Cienc. do Solo 32, 363-374. doi: 10.1590/S0100-06832008000 100034

Bardgett, R. D., Mommer, L., and de Vries, F. T. (2014). Going underground: Root traits as drivers of ecosystem processes. Trends Ecol. Evol. 29, 692-699. doi: $10.1016 /$ j.tree.2014.10.006

Barreto, C. V. G., Sakai, E., Arruda, F. B., Da Silva, E. A., and de Matos Pires, R. C. (2006). Distribuição espacial do sistema radicular do cafeeiro fertirrigado por gotejamento em campinas. Bragantia 65, 641-647. doi: 10.1590/S0006-87052006000400015

Bernardes, T. G., Da Silveira, P. M., Mesquita, M. A. M. H., de Aguiar, R. A., and Mesquita, G. M. H. (2010). Decomposição da biomassa e liberação de 
nutrientes dos capins braquiária e mombaça em condições de Cerrado. Pesqui. Agropecu. Trop. 40, 370-377. doi: 10.5216/pat.v40i3.5584

Bieluczyk, W., de Cássia Piccolo, M., Pereira, M. G., de Moraes, M. T., Soltangheisi, A., Bernardi, A. C., et al. (2020). Integrated farming systems influence soil organic matter dynamics in southeastern Brazil. Geoderma 371:114368. doi: 10.1016/j.geoderma.2020.114368

Bleby, T. M., Mcelrone, A. J., and Jackson, R. B. (2010). Water uptake and hydraulic redistribution across large woody root systems to $20 \mathrm{~m}$ depth. Plant Cell Environ. 33, 2132-2148. doi: 10.1111/j.1365-3040.2010.02212.x

Boddey, R. M., Rao, I. M., and Thomas, R. J. (1996). "Nutrient cycling and environmental impact of Brachiaria pastures," in Brachiaria: Biology, Agronomy and Improvement, eds J. W. Miles, B. L. Maass, and C. B. do Valle (Cali: Centro Internacional de Agricultura Tropical (CIAT)), 72-86.

Boddey, R. M., and Victoria, R. L. (1986). Estimation of biological nitrogen fixation associated with Brachiaria and Paspalum grasses using15N labelled organic matter and fertilizer. Plant Soil 90, 265-292. doi: 10.1007/BF02277403

Brady, N. C., and Weil, R. (2013). The Nature and Properties of Soil, 15th Edn. Porto Alegre: Pearson Education.

Bustamante, M. M. C., Corbeels, M., Scopel, E., and Roscoe, R. (2006). "Soil carbon and sequestration potential in Cerrado region in Brazil," in Carbon Sequestration in Soils of Latin America, eds R. Lal, C. C. Cerri, M. Bernoux, J. Etcherves, and C. E. P. Cerri (CRC Press), 285-304.

Byrnes, R. C., Nùñez, J., Arenas, L., Rao, I., Trujillo, C., Alvarez, C., et al. (2017). Biological nitrification inhibition by Brachiaria grasses mitigates soil nitrous oxide emissions from bovine urine patches. Soil Biol. Biochem. 107, 156-163. doi: 10.1016/j.soilbio.2016.12.029

Cantarella, H. (2007). "Nitrogênio," in Fertilidade do solo, eds R. F. Novais, V. H. A. Venegas, N. F. de Barros, R. L. F. Fontes, R. B. Cantarutti, and J. C. Lima (Viçosa: Sociedade Brasileira de Ciência do Solo), 375-470.

Cardoso, E. J. B. N., and Andreote, F. D. (2016). Microbiologia do Solo. Piracicaba: ESALQ.

Carvalho, J. L. N., Raucci, G. S., Cerri, C. E. P., Bernoux, M., Feigl, B. J., Wruck, F. J., et al. (2010). Impact of pasture, agriculture and crop-livestock systems on soil C stocks in Brazil. Soil Tillage Res. 110, 175-186. doi: 10.1016/j.still.2010.07.011

Carvalho, J. L. N., Raucci, G. S., Frazão, L. A., Cerri, C. E. P., Bernoux, M., and Cerri, C. C. (2014). Crop-pasture rotation: a strategy to reduce soil greenhouse gas emissions in the Brazilian Cerrado. Agric. Ecosyst. Environ. 183, 167-175. doi: 10.1016/j.agee.2013.11.014

Ceballos, G. A., Fabian, A. J., Oliveira Silva, J. C., Torino, A. B., and Bernardes, G. F. (2018). Production and speed of decomposition of species of soil coverage in direct sowing system. Rev. Ciências Agrárias 61:2631. doi: $10.22491 /$ rca.2018.2631

Ceccon, G. (2013). Consórcio Milho-Braquiária. Brasília: Embrapa.

Ceccon, G., Borghi, E., and Crusciol, C. A. C. (2013). "Modalidades e métodos implantação do consórcio milho-braquiária," in Consórcio Milho-Braquiária, ed G. Ceccon (Embrapa), 27-46.

Cherr, C. M., Scholberg, J. M. S., and McSorley, R. (2006). Green manure approaches to crop production: a synthesis. Agron. J. 98, 302-319. doi: 10.2134/agronj2005.0035

Chidowe, O. A., Blessing, A. D., Olalekan, O. J., Yetunde, O. E., and Mary, C. N. (2019). Tillage, Desmodium intortum, fertilizer rates for carbon stock, soil quality and grain yield in northern guinea savanna of Nigeria. Am. J. Clim. Chang. 08, 325-341. doi: 10.4236/ajcc.2019.82018

Clark, R. B., and Zeto, S. K. (2000). Mineral acquisition by arbuscular mycorrhizal plants. J. Plant Nutr. 23, 867-902. doi: 10.1080/01904160009382068

Costa, C. H. M., da Crusciol, C. A. C., Soratto, R. P., and Ferrari Neto, J. (2016). Taxas de decomposição e liberação de nutrientes da fitomassa de milheto, capim colonião e capim-braquiária. Biosci. J. 32, 1191-1203. doi: 10.14393/BJ-v32n5a2016-32982

Costa, N., de, L., Townsend, C. R., Magalhães, J. A., Fogaça, F. H. dos, S., and Santos, F. J. de S. (2017). Dinâmica do acúmulo de forragem e morfogênese de Urochloa brizantha cv. Xaraés sob períodos de descanso. Pubvet 11, 513-518. doi: 10.22256/pubvet.v11n5.513-518

Costa, N. R., Andreotti, M., Buzetti, S., Lopes, K. S. M., Santos, F. G., dos, and Pariz, C. M. (2014a). Acúmulo de macronutrientes e decomposição da palhada de braquiárias em razão da adubação nitrogenada durante e após o consórcio com a cultura do milho. Rev. Bras. Cienc. do Solo 38, 1223-1233. doi: 10.1590/S0100-06832014000400019
Costa, N. R., Andreotti, M., Fernandes, J. C., Cavasano, F. A., de Ulian, N. A., Pariz, C. M., et al. (2014b). Acúmulo de nutrientes e decomposição da palhada de braquiárias em função do manejo de corte e produção do milho em sucessão. Rev. Bras. Ciencias Agrar. 9, 166-173. doi: 10.5039/agraria.v9i2a3380

Costa, N. R., Andreotti, M., Ulian, N. D. A., Costa, B. S., Pariz, C. M., and Filho, M. C. M. T. (2015). Acúmulo de nutrientes e tempo de decomposição da palhada de espécies forrageiras em função de épocas de semeadura. Biosci. J. 31, 818-829. doi: 10.14393/BJ-v31n3a2015-22434

Costa, P. M., Villela, S. D. J., de Paula Leonel, F., do Carmo Araújo, S. A., Araújo, K. G., Ruas, J. R. M., et al. (2012). Intercropping of corn, brachiaria grass and leguminous plants: Productivity, quality and composition of silages. Rev. Bras. Zootec. 41, 2144-2149. doi: 10.1590/S1516-35982012001000002

Cruz, S. C. S., da Silva Pereira, F. R., Bicudo, S. J., de Albuquerque, A. W., Santos, J. R., and Machado C. G. (2008). Nutrição do milho e da Brachiaria decumbens cultivados em consórcio em diferentes preparos do solo. Acta Sci. Agron. 30, 733-739. doi: 10.4025/actasciagron.v30i5.5975

da Silva Ribeiro, N. V., Vidal, M. S., Barrios, S. C. L., Baldani, V. L. D., and Baldani, J. I. (2019). Genetic diversity and growth promoting characteristics of diazotrophic bacteria isolated from 20 genotypes of Brachiaria spp. Plant Soil. 451, 187-205. doi: 10.1007/s11104-019-04263-y

da Silva, E. V., Bouillet, J. P., de Moraes Gonçalves, J. L., Junior, C. H. A., Trivelin, P. C. O., Hinsinger, P., et al. (2011). Functional specialization of Eucalyptus fine roots: Contrasting potential uptake rates for nitrogen, potassium and calcium tracers at varying soil depths. Funct. Ecol. 25, 996-1006. doi: 10.1111/j.1365-2435.2011.01867.x

da Silva, H. M. S., Dubeux, J. C. B., Silveira, M. L., dos Santos, M. V. F., de Freitas, E. V., and de Andrade Lira, M. (2019). Root decomposition of grazed signalgrass in response to stocking and nitrogen fertilization rates. Crop Sci. 59, 811-818. doi: 10.2135/cropsci2018.08.0523

Dakora, F. D., and Phillips, D. A. (2002). Root exudates as mediators of mineral acquisition in low-nutrient environments. Plant Soil 245, 35-47. doi: 10.1023/A:1020809400075

de Barcellos Ferreira, A. C., Lamas, F. M., da Conceição Santana Carvalho, M., Salton, J. C., and Suassuna, N. D. (2010). Produção de biomassa por cultivos de cobertura do solo e produtividade do algodoeiro em plantio direto. Pesqui. Agropecu. Bras. 45, 546-553. doi: 10.1590/S0100-204X2010000 600003

de Deyn, G. B., Cornelissen, J. H. C., and Bardgett, R. D. (2008). Plant functional traits and soil carbon sequestration in contrasting biomes. Ecol. Lett. 11, 516-531. doi: 10.1111/j.1461-0248.2008.01164.x

de Figueiredo, E. B., Jayasundara, S., de Oliveira Bordonal, R., Berchielli, T. T., Reis, R. A., Wagner-Riddle, C., et al. (2017). Greenhouse gas balance and carbon footprint of beef cattle in three contrasting pasture-management systems in Brazil. J. Clean. Prod. 142, 420-431. doi: 10.1016/j.jclepro.2016.03.132

de la Jiménez, J. C., Kotula, L., Veneklaas, E. J., and Colmer, T. D. (2019). Rootzone hypoxia reduces growth of the tropical forage grass Urochloa humidicola in high-nutrient but not low-nutrient conditions. Ann. Bot. 1019-1032. doi: $10.1093 / \mathrm{aob} / \mathrm{mcz} 071$

de Magalhães, R. T., de Oliveira, I. P., and Kliemann, H. J. (2002). Relações da produção de massa seca e as quantidades de nutrientes exportadas por Brachiaria brizantha em solos sob o manejo pelo sistema "Barreirão." Pesqui. Agropecu. Bras. 32, 13-20.

de Oliveira, S. M., de Almeida, R. E. M., Pierozan-Junior, C., de Borja Reis, A. F., Souza, L. F. N., and Favarin, J. L. (2019). Contribution of corn intercropped with Brachiaria species to nutrient cycling. Pesqui. Agropecu. Trop. 49, 1-9. doi: 10.1590/1983-40632019v4955018

de Oliveira, S. M., Dias, D. S., de Borja Reis, A. F., Cruz, S. C. S., and Favarin, J. L. (2020). Vertical stratification of $\mathrm{K}$ uptake for soybean-based crop rotation. Nutr. Cycl. Agroecosystems 117, 185-197. doi: 10.1007/s10705-020-10059-9

Dias-Filho, M. B. (2016). Uso de Pastagens para a Produção de Bovinos de Corte no Brasil: Passado, Presente e Futuro. Brasília: Embrapa.

dos Santos, C. A., de Rezende, P. C., Machado Pinheiro, É. F., Pereira, J. M., Alves, B. J. R., Urquiaga, S., et al. (2019). Changes in soil carbon stocks after land-use change from native vegetation to pastures in the Atlantic forest region of Brazil. Geoderma 337, 394-401. doi: 10.1016/j.geoderma.2018.09.045

Dubeux, J. C. B., Sollenberger, L. E., Mathews, B. W., Scholberg, J. M., and Santos, H. Q. (2007). Nutrient cycling in warm-climate grasslands. Crop Sci. 47, 915-928. doi: 10.2135/cropsci2006.09.0581 
Dybzinski, R., Fargione, J. E., Zak, D. R., Fornara, D., and Tilman, D. (2008). Soil fertility increases with plant species diversity in a long-term biodiversity experiment. Oecologia 158, 85-93. doi: 10.1007/s00442-008-1123-x

Eri, M., da Silva Junior, C. A., Lima, M., La Scala Júnior, N., Oliveira-Júnior, J. F., de Teodoro, P. E., et al. (2020). Capitalizing on opportunities provided by pasture sudden death to enhance livestock sustainable management in Brazilian Amazonia. Environ. Dev. 33:100499. doi: 10.1016/j.envdev.2020.100499

Favarin, J. L., de Souza, L. T., Moscardini, D. B., and Baptistella, J. L. C. (2018). Caminhos para aumentar a produtividade do café arábica. Infom. Agron. 13-18.

Fisher, M. J., Rao, I. M., Ayarza, M. A., Lascano, C. E., Sanz, J. I., Thomas, R. J., et al. (1994). Carbon storage by introduced deep-rooted grasses in the South American savannas. Nature 371, 236-238. doi: 10.1038/371236a0

Foley, J. A., deFries, R., Asner, G. P., Barford, C., Bonan, G., Carpenter, S. R., et al. (2005). Global consequences of land use. Science 309, 570-574. doi: $10.1126 /$ science.1111772

Foxcroft, L. C., Richardson, D. M., Rejmánek, M., and Pyšek, P. (2010). Alien plant invasions in tropical and sub-tropical savannas: patterns, processes and prospects. Biol. Invasions 12, 3913-3933. doi: 10.1007/s10530-010-9823-7

Franco Junior, K. S., Florentino, L. A., de Souza Dias, M., and Franco, T. C. (2019). Influence of the use of coverage plants and the bioactivator in the physicalbiological characteristics of soil cultivated with coffee. Coffee Sci. 14, 116-122. doi: $10.25186 /$ cs.v14i1.1553

Frison, E. A., Cherfas, J., and Hodgkin, T. (2011). Agricultural biodiversity is essential for a sustainable improvement in food and nutrition security. Sustainability 3, 238-253. doi: 10.3390/su3010238

Galdos, M. V., Brown, E., Rosolem, C. A., Pires, L. F., Hallett, P. D., and Mooney, S. J. (2020). Brachiaria species influence nitrate transport in soil by modifying soil structure with their root system. Sci. Rep. 10:5072. doi: 10.1038/s41598-020-61986-0

Garcia, R. A., Crusciol, C. A. C., Calonego, J. C., and Rosolem, C. A. (2008). Potassium cycling in a corn-brachiaria cropping system. Eur. J. Agron. 28, 579-585. doi: 10.1016/j.eja.2008.01.002

Gerke, J. (2015). The acquisition of phosphate by higher plants: effect of carboxylate release by the roots. A critical review. J. Plant Nutr. Soil Sci. 178, 351-364. doi: 10.1002/jpln.201400590

Gerlach, A. G. X., da Silva, J. C., and Arf, O. (2019). Resposta do milho em consórcio com adubos verde no sistema plantio direto. Acta Iguazu 8, 134-146.

Gichangi, E. M., Njarui, D. M. G., and Gatheru, M. (2017). Plant shoots and roots biomass of brachiaria grasses and their effects on soil carbon in the semi-Arid tropics of Kenya. Trop. Subtrop. Agroecosyst. 20, 65-74.

Gil, J., Siebold, M., and Berger, T. (2015). Adoption and development of integrated crop-livestock-forestry systems in Mato Grosso, Brazil. Agric. Ecosyst. Environ. 199, 394-406. doi: 10.1016/j.agee.2014.10.008

Gill, R. A., and Jackson, R. B. (2000). Global patterns of root turnover for terrestrial ecosystems. New Phytol. 147, 13-31. doi: 10.1046/j.1469-8137.2000.00681.x

Gorgone-Barbosa, E., Pivello, V. R., Rissi, M. N., Zupo, T., and Fidelis, A. (2016). A importância da consideração de espécies invasoras no manejo integrado do fogo. Biodiv. Bras. 6, 27-40.

Guenni, O., Baruch, Z., and Marín, D. (2004). Responses to drought of five Brachiaria species. II. Water relations and leaf gas exchange. Plant Soil 258, 249-260. doi: 10.1023/B:PLSO.0000016555.53797.58

Hetrick, B. A. D., Wilson, G. W. T., and Todd, T. C. (1990). Differential responses of C3 and C4 grasses to mycorrhizal symbiosis, phosphorus fertilization, and soil microorganisms. Can. J. Bot. 68, 461-467. doi: 10.1139/b90-061

Hobbs, P. R., Sayre, K., and Gupta, R. (2008). The role of conservation agriculture in sustainable agriculture. Philos. Trans. R. Soc. B Biol. Sci. 363, 543-555. doi: 10.1098/rstb.2007.2169

Horrocks, C. A., Arango, J., Arevalo, A., Nuñez, J., Cardoso, J. A., and Dungait, J. A. J. (2019). Smart forage selection could significantly improve soil health in the tropics. Sci. Total Environ. 688, 609-621. doi: 10.1016/j.scitotenv.2019.06.152

Horwath, W. R. (2017). "The role of the soil microbial biomass in cycling nutrients," in Microbial Biomass, ed K. R. Tate (Europe: World Scientific), 41-66. doi: 10.1142/9781786341310_0002

IPCC (2019). 2019 Refinement to the 2006 IPCC Guidelines for National Greenhouse Gas Inventories. Switzerland: IPCC.

Ishikawa, T., Subbarao, G. V., Ito, O., and Okada, K. (2003). Suppression of nitrification and nitrous oxide emission by the tropical grass Brachiaria humidicola. Plant Soil 255, 413-419. doi: 10.1023/A:1026156924755
Janegitz, M. C., Inoue, B. S., and Rosolem, C. A. (2013). Formas de fósforo no solo após o cultivo de braquiária e tremoço branco. Ciência Rural 43, 1381-1386. doi: 10.1590/S0103-84782013000800007

Janegitz, M. C., Martins, A. R. H., and Rosolem, C. A. (2017). Cover crops and soil phosphorus availability. Commun. Soil Sci. Plant Anal. 48, 1240-1246. doi: 10.1080/00103624.2017.1341918

Jank, L., Santos, M. F., Valle, C. B., do, Barrios, S. C. L., and Resende, R. M. S. (2017). Novas Alternativas de Cultivares de Forrageiras e Melhoramento para a Sustentabilidade da Pecuária. Viçosa: Embrapa Gado Corte. Available online at: https://www.embrapa.br/busca-de-publicacoes/-/publicacao/1082385/ novas-alternativas-de-cultivares-de-forrageiras-e-melhoramento-para-asustentabilidade-da-pecuaria

Jank, L., Martuscello, J. A., do Valle, C. B., and Resende, R. M. S. (2011). "Panicum maximum," in Plantas Forrageiras, eds D. da Fonseca and J. A. Martucesllo (Universidade Federal de Viçosa), 166-196.

Johnston, A. E., Poulton, P. R., Fixen, P. E., and Curtin, D. (2014). "Phosphorus: its efficient use in agriculture," in Advances in Agronomy, ed D. L. Sparks (Cambridge: Academic Press), 177-228. doi: 10.1016/B978-0-12-420225-2.00005-4

Karia, C. T., de Andrade, R. P., Fernandes, C. D., and Shunke, R. M. (2011). "Gênero Stylosanthes," in Plantas Forrageiras, eds D. M. Da Fonseca and J. A. Martuscello (Viçosa: Universidade Federal de Viçosa - UFV), 366-401.

Karwat, H., Egenolf, K., Nuñez, J., Rao, I., Rasche, F., Arango, J., et al. (2018). Low $15 \mathrm{~N}$ natural abundance in shoot tissue of brachiaria humidicola is an indicator of reduced $\mathrm{N}$ losses due to biological nitrification inhibition (BNI). Front. Microbiol. 9:2383. doi: 10.3389/fmicb.2018.02383

Karwat, H., Moreta, D., Arango, J., Núñez, J., Rao, I., Rincón, Á., et al. (2017). Residual effect of BNI by Brachiaria humidicola pasture on nitrogen recovery and grain yield of subsequent maize. Plant Soil 420, 389-406. doi: 10.1007/s11104-017-3381-z

Keller-Grein, G., Maass, B. L., and Hanson, J. (1996). "Natural variation in Brachiaria and existing germplasm collections," in Brachiaria: Biology, Agronomy and Improvement, eds. J. W. Miles, B. L. Maass, and C. B. do Valle (Cali, Colômbia: Centro Internacional de Agricultura Tropical (CIAT)), 16-35.

Khan, Z. R., Pickett, J. A., Wadhams, L. J., Hassanali, A., and Midega, C. A. O. (2006). Combined control of Striga hermonthica and stemborers by maize-Desmodium spp. intercrops. Crop Prot. 25, 989-995. doi: 10.1016/j.cropro.2006.01.008

Kluthcouski, J., Cobucci, T., Aidar, H., Yokoyama, L. P., de Oliveira, I. P., da Costa, J. L., et al. (2000). Sistema Santa Fé-Tecnologia Embrapa: integração lavourapecuária pelo consórcio de culturas anuais com forrageiras, em áreas de lavoura, nos sistemas direto e convencional. Circ. Técnica 28. Available online at: http:// www.infoteca.cnptia.embrapa.br/bitstream/doc/208449/1/circ38.pdf

Kuzyakov, Y., and Domanski, G. (2000). Carbon input by plants into the soil. Review. J. Plant Nutr. Soil Sci. 163, 421-431. doi: 10.1002/1522-2624(200008)163:4<421::AID-JPLN421>3.0.CO;2-R

Lambers, H., Chapin, F. S., and Pons, T. L. (2008). Plant Physiological Ecology. New York, NY: Springer.

Lambers, H., Hayes, P. E., Laliberté, E., Oliveira, R. S., and Turner, B. L. (2015). Leaf manganese accumulation and phosphorus-acquisition efficiency. Trends Plant Sci. 20, 83-90. doi: 10.1016/j.tplants.2014.10.007

Lambers, H., Shane, M. W., Cramer, M. D., Pearse, S. J., and Veneklaas, E. J. (2006). Root structure and functioning for efficient acquisition of phosphorus: Matching morphological and physiological traits. Ann. Bot. 98, 693-713. doi: $10.1093 / \mathrm{aob} / \mathrm{mcl} 114$

Leite, M. R., Cassiolato, A. M. R., and Lannes, L. S. (2019). Urochloa decumbens Has Higher Mycorrhizal colonization in degraded than in pristine areas in the Brazilian Cerrado. Floresta e Ambient. 26:e20190060. doi: 10.1590/2179-8087.006019

Louw-Gaume, A. E., Rao, I. M., Gaume, A. J., and Frossard, E. (2010). A comparative study on plant growth and root plasticity responses of two Brachiaria forage grasses grown in nutrient solution at low and high phosphorus supply. Plant Soil 328, 155-164. doi: 10.1007/s11104-0090093-z

Louw-Gaume, A. E., Schweizer, N., Rao, I. M., Gaume, A. J., and Frossard, E. (2017). Temporal differences in plant growth and root exudation of two Brachiaria grasses in response to low phosphorus supply. Trop. GrasslandsForrajes Trop. 5:103. doi: 10.17138/TGFT(5)103-116 
Macedo, M. C. M. (2009). Integração lavoura e pecuária : o estado da arte e inovações tecnológicas. Crop and livestock integration: the state of the art and the near future. Rev. Bras. Zootec. 38, 133-146. doi: 10.1590/S1516-35982009001300015

Marchezan, C., Ferreira, P. A. A., Silva, L. S., Bacca, A., Krug, A. V., Nicoloso, F. T., et al. (2020). Nitrogen availability and physiological response of corn after 12 years with organic and mineral fertilization. J. Soil Sci. Plant Nutr. 1-11. doi: 10.1007/s42729-020-00185-2

Marschner, P. (2012). "Marschner's mineral nutrition of higher plants," in Third Edit, 3rd Edn., ed P. Marschner (San Diego: Academic Press), 315-330.

Martinelli, R., Monquero, P. A., Fontanetti, A., Conceição, P. M., and Azevedo, F. A. (2017). Ecological mowing: an option for sustainable weed management in young citrus orchards. Weed Technol. 31, 260-268. doi: 10.1017/wet.2017.3

Mekonnen, K., Buresh, R. J., and Jama, B. (1997). Root and inorganic nitrogen distributions in sesbania fallow, natural fallow and maize fields. Plant Soil 188, 319-327. doi: 10.1023/A:1004264608576

Menezes-Blackburn, D., Giles, C., Darch, T., George, T. S., Blackwell, M., Stutter, M., et al. (2017). Opportunities for mobilizing recalcitrant phosphorus from agricultural soils: a review. Plant Soil 427, 5-16. doi: 10.1007/s11104-017-3362-2

Midega, C. A. O., Pittchar, J., Salifu, D., Pickett, J. A., and Khan, Z. R. (2013). Effects of mulching, N-fertilization and intercropping with Desmodium uncinatum on Striga hermonthica infestation in maize. Crop Prot. 44, 44-49. doi: 10.1016/j.cropro.2012.10.018

Miles, J. W., Do Valle, C. B., Rao, I. M., and Euclides, V. P. B. (2004). "Brachiariagrasses," in Warm-Season (C4) Grasses, eds L. E. Moser, B. L. Burson, and L. E. Sollenburger (Madison, WI: Agronomy Monographs), 745-783. doi: 10.2134/agronmonogr45.c22

Momesso, L., Crusciol, C. A. C., Soratto, R. P., Vyn, T. J., Tanaka, K. S., Costa, C. H. M., et al. (2019). Impacts of nitrogen management on notill maize production following forage cover crops. Agron. J. 111, 639-649. doi: 10.2134/agronj2018.03.0201

Nakamura, T., Miranda, C. H. B., Ohwaki, Y., Valéio, J. R., Kim, Y., Macedo, M. C. M., et al. (2005). Characterization of nitrogen utilization by Brachiaria grasses in Brazilian savannas (cerrados). Soil Sci. Plant Nutr. 51, 973-979. doi: 10.1111/j.1747-0765.2005.tb00136.x

Neumann, G. (2016). The role of ethylene in plant adaptations for phosphate acquisition in soils-a review. Front. Plant Sci. 6:1224. doi: 10.3389/fpls.2015.01224

Neves, R. C., Vilar, C. C., Ushiwata, S. Y., and Costa, A. C. (2018). Persistência de palhada de Urochloa ruziziensis em sistema de plantio direto e convencional no município de Nova Xavantina-MT. Glob. Sci. Technol. 11, 110-122.

Nuñez, J., Arevalo, A., Karwat, H., Egenolf, K., Miles, J., Chirinda, N., et al. (2018). Biological nitrification inhibition activity in a soil-grown biparental population of the forage grass, Brachiaria humidicola. Plant Soil 426, 401-411. doi: $10.1007 / \mathrm{s} 11104-018-3626-5$

Oehl, F., Oberson, A., Tagmann, H. U., Besson, J. M., Dubois, D., Mäder, P., et al. (2002). Phosphorus budget and phosphorus availability in soils under organic and conventional farming. Nutr. Cycl. Agroecosyst. 62, 25-35. doi: 10.1023/A:1015195023724

Oliveira, I.., Kluthcouski, J., Yokoyama, L., Dutra, L. P., and de Portes, T. A. (1996). Sistema Barreirão recuperação renovação de pastagens. Embrapa 64:90.

Pacheco, L. P., Barbosa, J. M., Leandro, W. M., de Almedia Machado, P. L. O., de Assis, R. L., Madari, B. K., et al. (2013a). Ciclagem de nutrientes por plantas de cobertura e produtividade de soja e arroz em plantio direto. Pesqui. Agropecu. Bras. 48, 1228-1236. doi: 10.1590/S0100-204X2013000900006

Pacheco, L. P., de Sousa Monteiro, M. M., da Silva, R. F., dos Santos Soares, L., Fonseca, W. L., Petter, F. A., et al. (2013b). Produção de fitomassa e acúmulo de nutrientes por plantas de cobertura no cerrado piauiense. Bragantia 72, 237-246. doi: 10.1590/brag.2013.041

Pacheco, L. P., Leandro, W. M., de Almeida Machado, P. L. O., de Assis, R. L., Cobucci, T., Madari, B. E., et al. (2011). Produção de fitomassa e acúmulo e liberação de nutrientes por plantas de cobertura na safrinha. Pesqui. Agropecu. Bras. 46, 17-25. doi: 10.1590/S0100-204X2011000100003

Paul, B. K., Groot, J. C. J., Maass, B. L., Notenbaert, A. M. O., Herrero, M., and Tittonell, P. A. (2020). Improved feeding and forages at a crossroads: Farming systems approaches for sustainable livestock development in East Africa. Outlook Agric. 49, 13-20. doi: 10.1177/0030727020906170
Pedrosa, A. W. (2013). Eficiência da adubação nitrogenada no consórcio entre cafeeiro e Brachiaria brizantha. Piracicaba: ESALQ.

Pereira, L. E. T., Nishida, N. T., da Rocha Carvalho, L., and Herling, V. R. (2018). Recomendações para correção e adubação de pastagens Tropicais. Pirassununga: Universidade de São Paulo.

Pereira-Silva, E. F., Hardt, E., Biral, M. B., Keller, V. C., and Carvalho Delitti, W. B. (2019). Effects of recent ire on soil conditions and nutrient use of a native and an invasive grass in the Brazilian savanna. Ecoscience 26, 359-370. doi: 10.1080/11956860.2019.1613753

Pérez-Tienda, J., Valderas, A., Camañes, G., García-Agustín, P., and Ferrol, N. (2012). Kinetics of NH4+ uptake by the arbuscular mycorrhizal fungus Rhizophagus irregularis. Mycorrhiza 22, 485-491. doi: 10.1007/s00572-012-0452-0

Philp, J. N. M., Vance, W., Bell, R. W., Chhay, T., Boyd, D., Phimphachanhvongsod, V., et al. (2019). Forage options to sustainably intensify smallholder farming systems on tropical sandy soils. A review. Agron. Sustain. Dev. 39, 30. doi: 10.1007/s13593-019-0576-0

Pivello, N. I. A. R., Shida, U. N., and Meirelles, R. T. (1999a). Alien grasses in Brazilian savannas: a threat to the biodiversity. Biodivers. Conserv. 8, 1281-1294.

Pivello, V. R., Carvalho, V. M. C., Lopes, P. F., Peccinini, A. A., and Rosso, S. (1999b). Abundance and distribution of native and alien grasses in a "Cerrado" (Brazilian savanna) biological reserve. Biotropica 31:71. doi: 10.2307/2663960

Poirier, V., Roumet, C., and Munson, A. D. (2018). The root of the matter: Linking root traits and soil organic matter stabilization processes. Soil Biol. Biochem. 120, 246-259. doi: 10.1016/j.soilbio.2018.02.016

Postma, J. A., and Lynch, J. P. (2011). Theoretical evidence for the functional benefit of root cortical aerenchyma in soils with low phosphorus availability. Ann. Bot. 107, 829-841. doi: 10.1093/aob/mcq199

Power, A. G. (2010). Ecosystem services and agriculture: tradeoffs and synergies. Philos. Trans. R. Soc. B Biol. Sci. 365, 2959-2971. doi: 10.1098/rstb.2010. 0143

Quaggio, J. A., Thomaziello, R. A., Cantarella, H., and van Raij, B. (2018). Recomendações para calagem e adubação de café. in $1^{\circ}$ Simpósio sobre os avanços na nutrição de citros e café Campinas.

Ragassi, C. F., Pedrosa, A. W., and Favarin, J. L. (2013). Aspectos positivos e riscos no consórcio cafeeiro e braquiária. Rev. Visão Agríc. 12, 29-32.

Rao, I. M. (2001). “Adapting tropical forages to low-fertility soils," in Proceedings of the XIX International Grassland Congress (Cali: Centro Internacional de Agricultura Tropical (CIAT)), 247-254.

Rao, I. M., Ayarza, M. A., and Garcia, R. (1995). Adaptive attributes of tropical forage species to acid soils I. Differences in plant growth, nutrient acquisition and nutrient utilization among C4 grasses and C3 legumes. J. Plant Nutr. 18, 2135-2155. doi: 10.1080/01904169509365052

Rao, I. M., Kerridge, P. C., and Macedo, M. C. M. (1996). "Nutritional requirements of brachiaria and adaptation to acid soils," in Brachiaria: Biology, Agronomy and Improvement, eds C. B. Miles, W. M.John, and B. L. do Valle (Cali: Centro Internacional de Agricultura Tropical (CIAT)), 288.

Razuk, R. B. (2002). Avaliação do sistema radicular de acessos de Brachiaria brizantha e suas relações com atributos químicos e físicos do solo. Dourados: UFMS.

Reis, V. M., Dos Reis F. B. Jr., Quesada, D. M., de Oliveira, O. C. A., Alves, B. J. R, et al. (2001). Biological nitrogen fixation associated with tropical pasture grasses. Aust. J. Plant Physiol. 28, 837-844. doi: 10.1071/ PP01079

Rice, C. W., Rosolem, C. A., and Sarto, J. R. W. (2020). Deep soil carbon stock, origin, and root interaction in a tropical integrated crop-livestock system. Agrofor. Syst. 6, 1-20. doi: 10.1007/s10457-020-00505-6

Rocha, K. F., de Souza, M., Almeida, D. S., Chadwick, D. R., Jones, D. L., Mooney, S. J., et al. (2020a). Cover crops affect the partial nitrogen balance in a maize-forage cropping system. Geoderma 360:114000. doi: 10.1016/j.geoderma.2019.114000

Rocha, K. F., Kuramae, E. E., Borges, B. M. F., Leite, M. F. A., and Rosolem, C. A. (2020b). Microbial N-cycling gene abundance is affected by cover crop specie and development stage in an integrated cropping system. Arch. Microbiol. doi: 10.1007/s00203-020-01910-2. [Epub ahead of print].

Rodrigues, L. N., Marioti, J., and Roosevelt Júnior, A. (2011). "Índice de área foliar e profundidade radicular máxima das principais coberturas vegetais de uma 
bacia hidrográfica do bioma Cerrado," in XL Congresso Brasileiro de Engenharia Agrícola-CONBEA (Cuiabá).

Rodrigues, M., Pavinato, P. S., Withers, P. J. A., Teles, A. P. B., and Herrera, W. F. B. (2016). Legacy phosphorus and no tillage agriculture in tropical oxisols of the Brazilian savanna. Sci. Total Environ. 542, 1050-1061. doi: 10.1016/j.scitotenv.2015.08.118

Rosolem, C. A., Ritz, K., Cantarella, H., Galdos, M. V., Hawkesford, M. J., Whalley, W. R., et al. (2017). In Chapter Five-Enhanced Plant Rooting and Crop System Management for Improved $N$ Use Efficiency, ed D. L. Sparks (Cambridge: Academic Press), 205-239. doi: 10.1016/bs.agron.2017. 07.002

Rosolem, C. A., and Steiner, F. (2017). Effects of soil texture and rates of K input on potassium balance in tropical soil. Eur. J. Soil Sci. 68, 658-666. doi: $10.1111 /$ ejss. 12460

Santos, P. M., Primavesi, O. M., and de Bernardi, A. C. (2010). "Adubação de pastagens," in Bovinocultura de Corte, Vol. I, ed A. V. Pires (Piracicaba: FEALQ), 459-472.

Santos, P. M., Thornton, B., and Corsi, M. (2012). Adaptation of the C4 grass Panicum maximum to defoliation is related to plasticity of $\mathrm{N}$ uptake, mobilisation and allocation patterns. Sci. Agric. 69, 293-299. doi: 10.1590/S0103-90162012000500002

São Miguel, A. S. D. C., Pacheco, L. P., de Carvalho, Í. C., de Souza, E. D., Feitosa, P. B., and Petter, F. A. (2018). Phytomass and nutrient release in soybean cultivation systems under no-tillage|Fitomassa e liberação de nutrientes em sistemas de cultivo de soja sob plantio direto. Pesqui. Agropecu. Bras. 53, 1119-1131. doi: 10.1590/s0100-204x2018001000005

Saraiva, F. M., Dubeux, J. C. B., Lira, M. D. A., de Mello, A. C. L., Dos Santos, M. V. F., Cabral, F. D. A., et al. (2014). Root development and soil carbon stocks of tropical pastures managed under different grazing intensities. Trop. Grasslands Forrajes Trop. 2, 254-261. doi: 10.17138/TGFT(2)254-261

Silva, B. M., Oliveira, G. C., Serafim, M. E., Silva, É. A., Guimarães, P. T. G., Melo, L. B. B., et al. (2019). Soil moisture associated with least limiting water range, leaf water potential, initial growth and yield of coffee as affected by soil management system. Soil Tillage Res. 189, 36-43. doi: 10.1016/j.still.2018. 12.016

Silva, G. P., Roberto Ferreira Neves, J. C. L., and de Barros, N. F. (1992). Respostas de espécies de gramíneas forrageiras a camadas compactadas de solo. Rev. Ceres $39,31-43$.

Silva, L. L. G. G., Alves, G. C., Ribeiro, J. R. A., Urquiaga, S., Souto, S. M., Figueiredo, M. V. B., et al. (2010). Biological nitrogen fixation in grassland with different cutting intensities. Arch. Zootec. 59, 21-30. doi: $10.4321 /$ S0004-05922010000100003

Silva, M. L. N., Curi, N., Blancaneaux, P., Lima, J. M., de, and Carvalho, A. M. (1997). Rotação adubo verde-milho e adsorção de fósforo em Latossolo Vermelho-Escuro. Pesqui. Agropecu. Bras. 32, 649-654.

Simon, P. L., Dieckow, J., Zanatta, J. A., Ramalho, B., Ribeiro, R. H., van der Weerden, T., et al. (2020). Does Brachiaria humidicola and dicyandiamide reduce nitrous oxide and ammonia emissions from cattle urine patches in the subtropics? Sci. Total Environ. 720:137692. doi: 10.1016/j.scitotenv.2020.137692

Six, J., Bossuyt, H., Degryze, S., and Denef, K. (2004). A history of research on the link between (micro)aggregates, soil biota, and soil organic matter dynamics. Soil Tillage Res. 79, 7-31. doi: 10.1016/j.still.2004. 03.008

Smith, S. E., and Read, D. J. (2008). Mycorrhizal Symbiosis. Cambridge: Academic Press.

Soares, M. B., da S Freddi, O., da S Matos, E., Tavanti, R. F. R., Wruck, F. J., de Lima, J. P., et al. (2020). Integrated production systems: an alternative to soil chemical quality restoration in the Cerrado-Amazon ecotone. Catena 185:104279. doi: 10.1016/j.catena.2019.104279

Soratto, R. P., da Costa, C. H. M., Crusciol, C. A. C., Ferrari Neto, J., and Moro, E. (2019). Nitrogen fertilization on pearl millet and guinea grass: phytomass decomposition, cellulose, lignin, and nutrients release. Commun. Soil Sci. Plant Anal. 50, 1614-1623. doi: 10.1080/00103624.2019.1631327

Souza, L. S., Velini, E. D., Maimoni-Rodella, R. C. S., and Martins, D. (1999). Teores de macro e micronutrientes e a relação $\mathrm{C} / \mathrm{N}$ de várias espécies de plantas daninhas. Planta Daninha 17, 163-167. doi: 10.1590/S0100-83581999000100015
Stumpf, L., Pauletto, E. A., and Pinto, L. F. S. (2016). Soil aggregation and root growth of perennial grasses in a constructed clay minesoil. Soil Tillage Res. 161, 71-78. doi: 10.1016/j.still.2016.03.005

Subbarao, G. V., Nakahara, K., Hurtado, M. P., Ono, H., Moreta, D. E., Salcedo, A. F., et al. (2009). Evidence for biological nitrification inhibition in Brachiaria pastures. Proc. Natl. Acad. Sci. 106, 17302-17307. doi: 10.1073/pnas.0903694106

Subbarao, G. V., Rondon, M., Ito, O., Ishikawa, T., Rao, I. M., Nakahara, K., et al. (2007). Biological nitrification inhibition (BNI) - is it a widespread phenomenon? Plant Soil 294, 5-18. doi: 10.1007/s11104-006-9159-3

Subbarao, G. V., Sahrawat, K. L., Nakahara, K., Rao, I. M., Ishitani, M., Hash, C. T., et al. (2013). A paradigm shift towards low-nitrifying production systems: the role of biological nitrification inhibition (BNI). Ann. Bot. 112, 297-316. doi: $10.1093 / \mathrm{aob} / \mathrm{mcs} 230$

Sühs, R. B., Giehl, E. L. H., and Peroni, N. (2020). Preventing traditional management can cause grassland loss within 30 years in southern Brazil. Sci. Rep. 10:783. doi: 10.1038/s41598-020-57564-z

Sun, L., Lu, Y., Yu, F., Kronzucker, H. J., and Shi, W. (2016). Biological nitrification inhibition by rice root exudates and its relationship with nitrogenuse efficiency. New Phytol. 212, 646-656. doi: 10.1111/nph.14057

Syers, J. K., Johnston, A. E., and Curtin, D. (2008). Efficiency of Soil and Fertilizer Phosphorus Use: Reconciling Changing Concepts of Soil Phosphorus Behaviour With Agronomic Information. Rome: FAO Fertilizer and Plant Nutrition Bulletin 18

Tanaka, K. S., Crusciol, C. A. C., Soratto, R. P., Momesso, L., Costa, C. H. M., Franzluebbers, A. J., et al. (2019). Nutrients released by Urochloa cover crops prior to soybean. Nutr. Cycl. Agroecosyst. 113, 267-281. doi: 10.1007/s10705-019-09980-5

Tavanti, R. F. R., Montanari, R., Panosso, A. R., La Scala, N., Chiquitelli Neto, M., Freddi, O., et al. (2020). What is the impact of pasture reform on organic carbon compartments and $\mathrm{CO}_{2}$ emissions in the Brazilian Cerrado? Catena 194:104702. doi: 10.1016/j.catena.2020.104702

Teutscherova, N., Vazquez, E., Arevalo, A., Pulleman, M., Rao, I., and Arango, J. (2019). Differences in arbuscular mycorrhizal colonization and P acquisition between genotypes of the tropical Brachiaria grasses: is there a relation with BNI activity? Biol. Fertil. Soils 55, 325-337. doi: 10.1007/s00374-019-01353-y

Tian, J., and Liao, H. (2015). The role of intracellular and secreted purple acid phosphatases in plant phosphorus scavenging and recycling. Annu. Plant Rev. 48, 265-287. doi: 10.1002/9781118958841.ch10

Torres, J. L. R., de Assis, R. L., and Loss, A. (2018). Evolução entre os sistemas de produção agropecuária no Cerrado: convencional, Barreirão, Santa Fé e Integração lavoura pecuária. Inf. Agropec. 39, 7-17.

Torres, J. L. R., Pereira, M. G., and Fabian, A. J. (2008). Produção de fitomassa por plantas de cobertura e mineralização de seus resíduos em plantio direto Cover crops biomass production and its residues mineralization. Pesq. Agropec. Bras. 43, 421-428. doi: 10.1590/S0100-204X2008000300018

Trenkel, M. E. (2010). Slow and Controlled-Release and Stabilized Fertilizers: an Option for Enhancing Nutrient use Efficiency in Agriculture, 2nd Edn. Paris: International Fertilizer Industry Association (IFA).

Tully, K., and Ryals, R. (2017). Nutrient cycling in agroecosystems: balancing food and environmental objectives. Agroecol. Sustain. Food Syst. 41, 761-798. doi: 10.1080/21683565.2017.1336149

Urquiaga, S., Cadisch, G., Alves, B. J. R., Boddey, R. M., and Giller, K. E. (1998). Influence of decomposition of roots of tropical forage species on the availability of soil nitrogen. Soil Biol. Biochem. 30, 2099-2106. doi: 10.1016/S0038-0717(98)00086-8

Veenendaal, E. M., Monnaapula, S. C., Gilika, T., and Magole, I. L. (1992). Vesicular-arbuscular mycorrhizal infection of grass seedlings in a degraded semi-arid savanna in Botswana. New Phytol. 121, 477-485 doi: 10.1111/j.1469-8137.1992.tb02948.x

Villalba, H. A. G., Otto, R., Trivelin, P. C. O., and Leite, J. M. (2014). Fertilizantes nitrogenados: novas tecnologias. Inform. Agron. 148, 12-20.

Villegas, D., Arevalo, A., Nuñez, J., Mazabel, J., Subbarao, G., Rao, I., et al. (2020). Biological nitrification inhibition (BNI): phenotyping of a core germplasm collection of the tropical forage grass Megathyrsus maximus under greenhouse conditions. Front. Plant Sci. 11:820. doi: 10.3389/fpls.2020.00820

Vitousek, P. M., D’Antonio, C. M., Loope, L. L., and Westbrooks, R. (1996). Biological invasions as global environmental change. Am. Sci. 84, 468-478. 
Volpe, E., Macedo, M. C. M., Marchetti, M. E., and Lempp, B. (2006). “Métodos de recuperação direta de Brchiaria decumbens cv. Basilisk em Latossolo vermelho distrófico de cerrado," in IX Simpósio Nacional do Cerrado: Desafios e Estratégias para o Equilbrio entre Sociedade, Agronegócio e Recursos naturais (Brasília), $1-6$.

Wang, Y., Dong, X., Wang, H., Wang, Z., and Gu, J. (2015). Root tip morphology, anatomy, chemistry and potential hydraulic conductivity vary with soil depth in three temperate hardwood species. Tree Physiol. 36, 99-108. doi: 10.1093/treephys/tpv094

Wang, Y., and Lambers, H. (2020). Root-released organic anions in response to low phosphorus availability: recent progress, challenges and future perspectives. Plant Soil 447, 135-156. doi: 10.1007/s11104-019-03972-8

Wenzl, P., Chaves, A. L., Patiño, G. M., Mayer, J. E., and Rao, I. M. (2002). Aluminum stress stimulates the accumulation of organic acids in root apices of Brachiaria species. J. Plant Nutr. Soil Sci. 165, 582-588. doi: 10.1002/1522-2624(200210)165:5<582::AID-JPLN582>3.0.CO;2-W

Werner, J. C., Paulino, V. T., Cantarella, H., de Andrade, O. N., and Quaggio, J. A. (1997). "Forrageiras," in Boletim Técnico 100-Recomendações de adubação e calagem para o estado de São Paulo, eds R. B. Van, H. Cantarella, J. A. Quaggio, and A. M. C. Furlani (Campinas: IAC/Fundag), 261-276.

Wutke, E. B., Calegari, A., and Wildner, L. do P. (2014). "Espécies de adubos verdes e plantas de cobertura e recomendações para seu uso," in Adubação verde e Plantas de Cobertura no Brasil: Fundamentos e Práticas (Brasília), $59-168$.
Xue, Y., Xia, H., Christie, P., Zhang, Z., Li, L., and Tang, C. (2016). Crop acquisition of phosphorus, iron and zinc from soil in cereal/legume intercropping systems: a critical review. Ann. Bot. 117, 363-377. doi: 10.1093/aob/mcv182

Yé, L., Lata, J.-C., Masse, D., Nacro, H. B., Kissou, R., Diallo, N. H., et al. (2017). Contrasted effects of annual and perennial grasses on soil chemical and biological characteristics of a grazed Sudanian savanna. Appl. Soil Ecol. 113, 155-165. doi: 10.1016/j.apsoil.2017.02.003

Zaia, F. C., Da Gama-Rodrigues, A. C., Da Gama-Rodrigues, E. F., and Machado, R. C. R. (2008). Fósforo orgânico em solos sob agrossistemas de cacau. Rev Bras. Cienc. do Solo 32, 1987-1995. doi: 10.1590/S0100-06832008000500020

Zenni, R. D., and Ziller, R. S. (2011). An overview of invasive plants in Brazil. Rev. Bras. Bot. 34, 431-446. doi: 10.1590/S0100-84042011000300016

Conflict of Interest: The authors declare that the research was conducted in the absence of any commercial or financial relationships that could be construed as a potential conflict of interest.

Copyright (๑) 2020 Baptistella, de Andrade, Favarin and Mazzafera. This is an openaccess article distributed under the terms of the Creative Commons Attribution License (CC BY). The use, distribution or reproduction in other forums is permitted, provided the original author $(s)$ and the copyright owner(s) are credited and that the original publication in this journal is cited, in accordance with accepted academic practice. No use, distribution or reproduction is permitted which does not comply with these terms. 